Notre Dame Law Review

Volume 85 | Issue 3

Article 3

$3-1-2010$

\title{
Deciphering the Chemical Soup: Using Public Nuisance to Compel Chemical Testing
}

Albert C. Lin

Follow this and additional works at: http://scholarship.law.nd.edu/ndlr

\section{Recommended Citation}

Albert C. Lin, Deciphering the Chemical Soup: Using Public Nuisance to Compel Chemical Testing, 85 Notre Dame L. Rev. 955 (2010). Available at: http://scholarship.law.nd.edu/ndlr/vol85/iss3/3

This Article is brought to you for free and open access by NDLScholarship. It has been accepted for inclusion in Notre Dame Law Review by an authorized administrator of NDLScholarship. For more information, please contact lawdr@nd.edu. 


\title{
DECIPHERING THE CHEMICAL SOUP: USING PUBLIC NUISANCE TO COMPEL CHEMICAL TESTING
}

\begin{abstract}
Albert C. Lin*
The problem of toxic ignorance plagues modern society. On a daily basis, each of us is exposed to hundreds of chemicals, the vast majority of which have been subject to little or no testing to determine whether they are toxic to humans or the environment. Many of these chemicals may turn out to be harmless. Some, however, may cause cancer, reproductive defects, and other harms. In toto, chemicals are believed to be responsible for tens of thousands of deaths per year. The systematic failure of manufacturers and distributors to test chemical substances is a rational response to marketplace incentives, tort liability miles, and existing chemical regulations. To address the problem of toxic ignorance, this Article proposes the recognition of a new type of public nuisance to compel chemical testing. In contrast to conventional toxic tort litigation, which requires a showing of physical injury, the failure to test itself would constitute a public nuisance. Inadequate testing puts the public health at risk, and the resultant lack of information undermines the ability of govermments and individuals to protect public health. In addition to explaining the basis for applying public nuisance doctrine to the failure to test, the Article also examines practical considerations relating to how courts would enforce the duty to conduct testing.

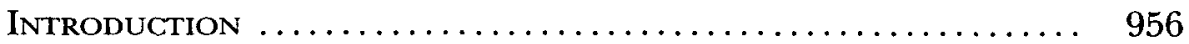

I. The Problem of Toxic Ignorance $\ldots \ldots \ldots \ldots \ldots \ldots \ldots . \ldots 98$

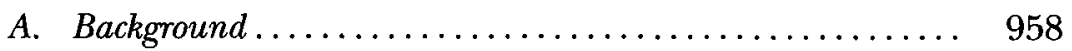

(C) 2010 Albert C. Lin. Individuals and nonprofit institutions may reproduce and distribute copies of this Article in any format, at or below cost, for educational purposes, so long as each copy identifies the author, provides a citation to the Notre Dame Law Review, and includes this provision and copyright notice.

* Professor of Law, University of California, Davis, School of Law. Thanks to John Applegate, Donald Gifford, Margaret Johns, and Wendy Wagner for thoughtful feedback. Thanks also to Dean Kevin Johnson, Associate Dean Vik Amar, and the U.C. Davis School of Law for financial support for this project, and to Elizabeth Kinsella for her outstanding research assistance.
\end{abstract}


B. Incentives Not to Test ...................... 961

C. Tort Law Exacerbates the Ignorance Problem ........... 963

1. The Duty to Test..................... 963

2. Difficulties in Enforcing the Duty to Test ....... 965

D. TSCA Makes Matters Worse.................. 967

1. TSCA Does Not Require Toxicity Testing ........ 968

2. TSCA Creates Disincentives to Test ......... 970

3. The HPV Challenge Program Has Done Little to Bridge the Data Gap ................. 970

II. Articulating an Enforceable Duty to Test in Public

Nuisance Doctrine........................ 972

A. Public Nuisance Doctrine ....................... 972

B. Applying Public Nuisance Doctrine to the Failure to Test ... 980

C. An Alternative Public Nuisance Theory Centered on the Right to Information......................... 987

D. Litigating Public Nuisance for Failure to Test......... 990

E. Other Proposals......................... 994

1. Liability Without Causation............... 994

2. Statutory Reform ................... 996

III. What Might a Duty to Test Require? ........... 1000

A. Toxicity Testing Methods in General .............. 1000

B. In Vitro and In Vivo Testing ................. 1002

1. In Vitro Methods .................... 1002

2. In Vivo Methods .................... 1004

C. Applying the Duty to Test in Specific Instances ......... 1006

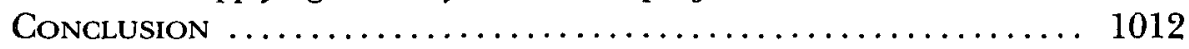

\section{INTRODUCTION}

We live in a chemical soup. On a daily basis, each of us is exposed to hundreds of chemicals, the vast majority of which have been subject to little or no testing to determine whether they are toxic to humans or the environment. ${ }^{1}$ Many of these chemicals will turn out to be harmless, but others will have detrimental or even devastat-

1 See Marla Cone, Chemicals Get the Safe Treatment, L.A. Times, Sept. 14, 2008, at A1 (reporting that tests of umbilical cords show that a newborn's body contains nearly 300 chemical compounds); Douglas Fischer, Study Ties Pollution to Cancer, OAKLAND TrIB., May 14, 2007, at 1 (reporting that " $[\mathrm{w}]$ omen face daily and widespread exposure to hundreds of chemicals linked to breast cancer"); Douglas Fischer, The Great Experiment, OAKLAND TRIB., Mar. 10, 2005, http://www.insidebayarea.com/ bodyburden/ci_2600903 (stating that " $t$ ] housands of chemicals are found in everyday consumer products" and that "EPA has full toxicity data for about 25 percent [of them]"); see also Ctrs. for Disease Control \& Prevention, U.S. Dep't Health \& Human Servs., Fourth National Report on Human Exposure to Environmental 
ing effects that will become apparent only with the passage of time. The problem of toxic ignorance is widely recognized, yet legislatures, regulatory agencies, courts, and the chemical industry have done relatively little to address the problem. Without analyzing the risks posed by chemicals before they become widely distributed, it is difficult to determine the precautions that should be taken or the scope of any health and environmental problems that may result. Experiences in which we have discovered the hazards of chemical substances belatedly-ranging from asbestos to benzene to polychlorinated biphenyls (PCBs)-illustrate the potentially broad and serious consequences of toxic ignorance. ${ }^{2}$

Uncertainty is a constant companion in scientists' efforts to understand the phenomena occurring around us, and the field of toxicology is no exception to that principle. ${ }^{3}$ Rarely do we know as much as we would like to know about cause-and-effect relationships. Yet the level of toxic ignorance that surrounds us is not the inevitable result of the limits of scientific inquiry. Rather, it is the consequence of deliberate decisions by the chemical industry and by those who incorporate chemicals into their manufacturing processes to avoid testing that would identify at least some of the likely harms.

CHEmincals (2009), available at http://www.cdc.gov/exposurereport/pdf/FourthReport.pdf (providing recent assessment of human chemical exposure).

2 See David Gee \& Morris Greenberg, Asbestos: From 'Magic' to Malevolent Mineral, in The Precautionary Principle in the 20th Century 49 (Poul Harremoès et al. eds., 2002) (describing the toxic effects of asbestos exposure); Peter F. Infante, Benzene: A Historical Perspective on the American and European Occupational Setting, in $\mathrm{T}_{\mathrm{HE}}$ Precautionary Principle in the 20Th Century, supra, at 35-36 (describing poisonous and carcinogenic effects of use of benzene as solvent); Janna G. Koppe \& Jane Keys, PCBs and the Precautionary Principle, in The Precautionary Principle in THE 20TH Century, supra, at 64, 64 (describing toxic effects of PCBs, a class of organic compounds widely used as insulators in electrical equipment). Scientists estimate that during its peak use, asbestos was responsible for hundreds, if not thousands of deaths per year in the United States. See Malcolm Ross, A Survey of Asbestos-Related Disease in Trades and Mining Occupations and in Factory and Mining Communities as a Means of Predicting Health Risks of Nonoccupational Exposures to Fibrous Minerals, in Definitions for Asbestos and Other Health-Related Silicates 51, 89-90, 96-97 (Benjamin Levadie ed., 1984); see also Gee \& Greenberg, supra, at 49 (estimating 250,000 to 400,000 deaths will be caused by asbestos in the European Union within a 35-year period).

3 See Comm. on Improving Risk Analysis ApProaches USED by the U.S. EPA, Nat'l Research Council, Science and Decisions 4 (2009) [hereinafter Nat'l Research Council, ScIEnce AND Decisions], available at http://www.nap.edu/ openbook.php? record_id=12209 (describing uncertainty as "an inherent property of scientific data"); Albert C. Lin, The Unifying Role of Harm in Environmental Law, 2006 WIS. L. REv. 897, 968-69 (discussing uncertainty associated with toxic exposure). 
A regulatory mandate to conduct comprehensive testing is one possible response to the problem, but such an approach would meet formidable political resistance. It might also require significant resources and drive useful chemicals from the market. In the absence of such a mandate, this Article proposes the use of public nuisance litigation for attacking the toxic ignorance problem. Part I of the Article explains the problem of toxic ignorance and identifies various economic and legal disincentives for chemical manufacturers to conduct toxicity testing. In response to this problem, Part II proposes the recognition and use of a public nuisance action against chemical manufacturers, processors, and importers for the failure to test chemical substances. Finally, Part III examines the important practical question of how courts might enforce the duty to test against chemical companies; this section describes various methods of toxicity testing and suggests guidelines for courts to consider.

\section{The Problem of Toxic Ignorance}

\section{A. Background}

According to some estimates, chemical exposure is responsible for tens of thousands of deaths per year in the United States. ${ }^{4}$ Nonetheless, we have surprisingly little information about the health and environmental effects of the thousands of chemicals that we use on a daily basis. ${ }^{5}$ A 1998 Environmental Protection Agency (EPA) study of toxicity data on high production volume (HPV) chemicals-those

4 See Christine H. Kim, Piercing the Veil of Toxic Ignorance: Judicial Creation of Scientific Research, 15 N.Y.U. ENVTL. L.J. 540, 542 (2007) (reporting an estimated 33,900 annual United States cancer deaths from occupational and environmental exposure to pollutants); David Pimentel et al., Ecology of Increasing Disease: Population Growth and Environmental Degradation, 48 BIoSCIENCE 817, 817, 819 (1998) (noting estimate of 30,000 cancer-related deaths per year in the United States attributable to chemical exposure and calculating that " $40 \%$ of world deaths can be attributed to various environmental factors, especially organic and chemical pollutants"); see also COMM. ON Developmental Toxicology, Nat'l Research Council, Scientific Frontiers in Developmental Toxicolocy AND Risk Assessment 1 (2000), available at http:// books.nap.edu/openbook.php?record_id=9871 (estimating that $3 \%$ of approximately 120,000 birth defects in the United States per year are attributable to exposure to toxic chemicals and physical agents).

5 See John S. Applegate, Bridging the Data Gap: Balancing the Supply and Demand for Chemical Information, 86 TEx. L. REv. 1365, 1381-83 (2008) (discussing lack of information); Wendy E. Wagner, Commons Ignorance: The Failure of Environmental Law to Produce Needed Information on Health and the Environment, 53 DuKE L.J. 1619, 1625-30 (2004) (describing lack of monitoring information, toxicity testing, and theoretical understanding regarding how hazardous substances affect human health and environment). 
three thousand or so chemicals imported or produced in the United States in a volume of over one million pounds per year-found no toxicity information publicly available for nearly half of the chemicals identified. ${ }^{6}$ For only a handful of these chemicals-seven percentwas a full set of basic toxicity information available. ${ }^{7}$ While voluntary efforts in the last decade have sought to collect or generate more information on the potential toxic effects of HPV chemicals, significant information gaps remain. ${ }^{8}$ Toxicity data is even more lacking for the 80,000 or so non-HPV chemicals found in commerce today. ${ }^{9}$

Expert panels and government agencies have decried the lack of toxicity testing, ${ }^{10}$ and even the chemical industry has acknowledged the wide information gap. ${ }^{11}$ Hundreds of new chemicals enter the

6 Office of Pollution Prevention \& Toxics, Envtl. Protection Agency, Chemical Hazard Data Avallability Study 2 (1998) [hereinafter EPA, Chemical HAZARD DATA], available at http://www.epa.gov/HPV/pubs/general/hazchem.pdf; see also Envtl. Health Program, Envtl. Def. Fund, Toxic Ignorance 7, 15 (1997), available at http://www.edf.org/documents/243_toxicignorance.pdf (reporting, based on sample of $100 \mathrm{HPV}$ chemicals, that "even the most basic toxicity testing results cannot be found in the public record for nearly $75 \%$ of the top-volume chemicals in commercial use"). An earlier study by the National Research Council of the National Academy of Sciences found similar information gaps. See Nat'L ResearciH Council, Nat'l Acad. Of Scis., Toxicity Testing 12 fig. 2 (1984), available at http:// books.nap.edu/openbook.php?record_id=317 (finding "minimal" toxicity information available for only twenty-two percent of high volume chemicals).

7 See EPA, Chemical. Hazard Data, supra note 6, at 2.

8 See infra Part I.D.3.

9 See Ctrs. for Occupational \& Envtl. Health, Univ. of Cal., Green ChemisTRY 1 (2008), available at http://coeh.berkeley.edu/docs/news/green_chem_brief. pdf (" $[\mathrm{H}]$ ealth and environmental effects of the great majority [of such chemicals] ... are largely unknown."); U.S. Gov't Accountability Office, Chemical RegulaTION 1-2 (2005) [hereinafter GAO, CHEMICAL RECULATION], available at http://www. gao.gov/new.items/d05458.pdf (stating there are over 82,000 chemicals listed in EPA's Toxic Substances Control Act (TSCA) inventory); Applegate, supra note 5, at 1383 (contending that studies finding data gap for chemical testing likely understate extent of problem because studies focus on HPV chemicals, for which presumably greatest amount of data exists).

10 See Wendy Wagner, Using Competition-Based Regulation to Bridge the Toxics Data Gap, 83 IND. L.J. 629, $636 \&$ n.40 (2008) (listing studies that recommend more toxicity testing).

11 See EPA, Chemical Hazard Data, supra note 6, at 4 (discussing analysis by Chemical Manufacturers Association concluding that forty-seven percent of chemicals studied had full screening information data); of. Testimony of Michael $P$. Wilson, $P h D$, MPH, Univ. of Cal., Berkley Before the S. Comm. on Env't $\mathcal{E}^{\mathcal{O} P u b .}$ Works, 109th Cong. 2 (2006), available at http://epw.senate.gov/109th/Wilson_Testimony.pdf (describing inability of manufacturers and other businesses to identify and replace hazardous chemicals); Mark Schapiro, Toxic Inaction: Why Poisonous, Unregulated Chemicals End Up 
flow of commerce each year, exacerbating the situation. ${ }^{12}$ With the commercialization of nanotechnology, a rapidly developing field that is creating substances with new physical and chemical properties and often unknown toxicological effects, the information gap threatens to expand into an information chasm. ${ }^{13}$

Toxicity information is essential to EPA, the Occupational Safety and Health Administration, and other regulatory agencies whose mission is to protect public health and the environment. The absence of toxicity data hampers these agencies' ability to carry out basic regulatory tasks such as conducting risk assessments, developing safety guidelines, setting regulatory standards, defending regulations from legal challenges, and warning the public about potential hazards. ${ }^{14}$ Ultimately, the information gap leaves the government unable to protect the public and the public unable to protect itself.

Lack of toxicity information undermines the tort system as well. Ideally, toxic tort claims further social goals of compensation, deterrence, and corrective justice. ${ }^{15}$ Injured plaintiffs receive compensation for their harms, potential defendants are deterred by the threat of liability, and those entities responsible for plaintiffs' harms are required to restore plaintiffs to their original position. ${ }^{16}$ In reality, however, environmental toxic tort plaintiffs are frustrated by gaps in knowledge regarding causation, risk, and harm. ${ }^{17}$ Often the most significant of these obstacles is causation. ${ }^{18}$ Toxicity testing has the

in Our Blood, Harper's MaG., Oct. 2007, at 78, 80-81 (reporting chemical industry representative's praise of ineffective toxic regulatory statute).

12 See U.S. Gov't Accountability OfFice, supra note 9, at 1-2 (noting over seven hundred new chemicals are introduced into commerce each year).

13 See Jeffrey Rudd, Regulating the Impacts of Engineered Nanoparticles Under TSCA: Shifting Authority from Industry to Government, 33 ColuM. J. ENVTL. L. 215, 229 (2008) (expressing concerns regarding prioritization of "commercialization of nanoparticles over the EPA's ability to assess and regulate the risks that nanoparticles pose to public health and the environment"). See generally Albert C. Lin, Size Matters: Regulating Nanotechnology, 31 HARV. ENVTL. L. REV. 349 (2007) (arguing that existing regulatory authority is inadequate to handle developments in nanotechnology and proposing a new legislative framework).

14 See EPA, Chemical Hazard Data, supra note 6, at 2.

15 See Albert C. Lin, Beyond Tort: Compensating Victims of Environmental Toxic Injury, 78 S. CAL. L. REv. 1439, 1452-60 (2005) (discussing objectives of tort system and how latency and difficulties in proving causation undermine the system's ability to achieve these objectives).

16 See id. at 1453.

17 See id. at 1441.

18 See Margaret A. Berger, Eliminating General Causation: Notes Towards a New Theory of Justice and Toxic Torts, 97 CoLuM. L. REv. 2117,2120 (1997) (“[C]ausation is the central, decisive factor in mass tort litigation."). 
potential to generate information on the ability of a chemical to cause illness, but the lack of such testing often prevents plaintiffs from establishing a prima facie case. Even when the available data is sufficient to support a regulatory response, it is usually insufficient to support a finding of causation in an individual tort case. ${ }^{19}$ In these cases, courts often require proof that exposure to a chemical doubled the plaintiff's risk of harm, or they may demand particularistic proof of a causal connection. ${ }^{20}$ Magnifying the difficulty of the task faced by toxic tort plaintiffs, the Supreme Court's decision in Daubert v. Merrell Dow Pharmaceuticals, Inc. ${ }^{21}$ established a rigorous standard for admitting scientific expert testimony. Daubert made clear that federal trial judges must serve as gatekeepers for scientific testimony by examining for themselves the reliability of the methods underlying expert testimony. ${ }^{22}$ The application of Daubert in toxic tort cases has led many courts to reject proposed expert testimony, particularly that proffered by plaintiffs, as too unreliable in light of scientific uncertainty and incomplete scientific knowledge. ${ }^{23}$

\section{B. Incentives Not to Test}

The toxic ignorance problem is the unsurprising result of rational decisions by chemical manufacturers not to conduct extensive testing. ${ }^{24}$ Our legal system generally assumes that chemicals are "innocent until proven guilty"; we restrict chemical manufacture and

19 See Richard J. Pierce, Jr., Causation in Govermment Regulation and Toxic Torts, 76 WASH. U. L.Q. 1307, 1307 (1998) (explaining that in "deciding whether to impose a regulatory restriction, the agency asks whether there is sufficient evidence of a general causal relationship between substance $A$ and injury $X$ to justify imposition of a regulatory restriction," whereas in a tort case, a court must decide the distinct question of "whether a particular manufacturer of substance $A$ is legally and financially responsible for a particular injury to a particular individual"). In the narrower context of product liability actions involving exposure to potentially toxic substances, causation poses a less imposing barrier. In such actions, plaintiffs may be able to establish liability based on a failure to warn that a product might be harmful, without having to demonstrate by a preponderance of the evidence that the product is harmful. See Mark Geistfeld, Scientific Uncertainty and Causation in Tort Law, 54 VAND. L. REV. 1011, 1018 (2001).

20 See Lin, supra note 15 , at $1449-51 \& n .45$ (noting cases involving specific causation in environmental toxic injuries).

21509 U.S. 579 (1993).

22 See id. at 589-95.

23 See Margaret A. Berger \& Aaron D. Twerski, Uncertainty and Informed Choice: Unmasking Daubert, 104 MicH. L. Rev. 257, 258, 260-67 (2005) (contending that toxic tort plaintiffs' difficulties "have increased exponentially" as result of Daubert); Lin, supra note 15 , at $1451 \& \mathrm{n} .54$ (citing cases and commentary).

24 See Wagner, supra note 5, at 1622-25. 
distribution only if and when harm is demonstrated. ${ }^{25}$ To make matters worse, the system largely excuses manufacturers from having to produce toxicity information, and as described further below, even gives manufacturers incentives not to test. In theory, government agencies, consumer organizations, and others can step in and perform toxicological research on their own. These actors, however, rarely have the resources to do so. ${ }^{26}$ In addition, they may not be able to access the information needed to conduct safety testing because of trade secret claims by manufacturers. ${ }^{27}$ Consequently, society relies heavily on chemical manufacturers to do the testing themselves. ${ }^{28}$

Manufacturers have the greatest familiarity with their products and the most opportunities to learn about them, can channel the results of safety testing back into product design to avoid injuries, and can spread the costs of testing among customers. ${ }^{29}$ Various factors discourage manufacturers from generating toxicity information, however. First, thorough toxicity testing can be expensive, and manufacturers cannot easily profit from investments in producing toxicity data. $^{30}$ In ordinary product development research, companies transform knowledge from that research into private gain through the

25 See Carl F. Cranor, Do You Want to Bet Your Children's Health on Post-Market Harm Principles? An Argument for a Trespass or Permission Model for Regulating Toxicants, 19 VILL. ENVTL. L.J. 251, 252 (2008). See generally Lin, supra note 3 (contending that environmental law has generally responded to demonstrated harm).

26 See John S. Applegate, The Perils of Unreasonable Risk: Information, Regulatory Policy, and Toxic Substances Control, 91 Colum. L. Rev. 261, 298-99 (1991) ("Toxicology information is too expensive for workers and consumers (or even unions and consumer organizations) to generate."); $i d$. at $306-07$ (concluding that "[t]here will never be enough money in a federal or state budget to fill the existing data gaps on a chemical-by-chemical basis," given the number of substances for which testing would be required); Wendy E. Wagner, Choosing Ignorance in the Manufacture of Toxic Products, 82 CoRNell L. REv. 773, 789 (1997).

27 See Wagner, supra note 26, at 798; Wagner, supra note 5, at 1645, 1699-1705. See generally Thomas O. McGarity \& Sidney A. Shapiro, The Trade Secret Status of Health and Safety Testing Information: Reforming Agency Disclosure Policies, 93 HARv. L. REv. 837 (1980) (arguing for broad disclosure of health and safety data, notwithstanding trade secret claims).

28 See Applegate, supra note 26, at 299.

29 See Wagner, supra note 26, at 798-802.

30 See Mary L. Lyndon, Information Economics and Chemical Toxicity: Designing Laws to Produce and Use Data, 87 MicH. L. REv. 1795, 1813 (1989) (noting that benefits from toxicological research, including health information and identification of externalities, "may not be recovered by individual firms, or their impact may not be easily identifiable as the results of one company's research"); Wagner, supra note 5, at 1634-35 (noting high out-of-pocket costs associated with safety research); see also Jennifer H. Arlen, Compensation Systems and Efficient Deterrence, 52 MD. L. REv. 1093, 1121 (1993) ("Manufacturers do not benefit from proving that their product is free from a 
development and sale of marketable products. ${ }^{31}$ By contrast, it is much more difficult for private entities to capture the value of information generated from toxicity research. ${ }^{32}$ Indeed, from a company's perspective, investment in such research is risky if not unwise. ${ }^{33}$ It is impossible for studies to establish that a substance poses no risks at all, whereas results suggesting a potential hazard could trigger negative publicity as well as an obligation to do additional, more costly testing. ${ }^{34}$ Moreover, because of the long-term and latent effects frequently involved in toxic exposure, chemical toxicity is not readily visible to consumers. ${ }^{35}$ This gives manufacturers little economic incentive to undertake research that might only identify and document toxic effects. ${ }^{36}$ In the resultant market, untested chemicalswhich will appear to the consumer to pose no detrimental risks-possess an advantage over chemicals having some indication of potential toxicity. ${ }^{37}$ Although it is theoretically possible for a manufacturer to gain a commercial advantage by marketing a tested product as "safe," the ease of making such claims and the difficulty of verifying them often lead consumers to discount them. ${ }^{38}$

\section{Tort Law Exacerbates the Ignorance Problem}

\section{The Duty to Test}

In theory, liability rules promote toxicity research by giving manufacturers an incentive to ensure that their products are reasonably safe. Indeed, tort law imposes on manufacturers an unequivocal duty to test their products for dangers associated with their use. ${ }^{39}$ This

risk-if indeed it is-if consumers do not expect the product to be risky in the first place.").

31 See Wagner, supra note 5, at 1631.

32 See Lyndon, supra note 30, at 1813; Wagner, supra note 5, at 1631-32.

33 See Lyndon, supra note 30, at 1813; Wagner, supra note 5, at 1631-32.

34 See Wagner, supra note 5, at 1635-36.

35 See Lin, supra note 15 , at 1446.

36 See Applegate, supra note 26, at 299; Lyndon, supra note 30, at 1813-14; Alan Schwartz, Products Liability, Corporate Structure, and Bankruptcy: Toxic Substances and the Remote Risk Relationship, 14 J. LEGAL STUd. 689, 700-01, 710 (1985); Wagner, supra note 5, at 1631-32. Moreover, corporate managers face short-term profit motivations that further disfavor testing. See Berger, supra note 18, at 2138-39; Wagner, supra note 26 , at 785 .

37 See Lyndon, supra note 30 , at 1814.

38 See id. at 1816 ("Even when privately produced information is of high quality, the commercial context diminishes its credibility and, thus, its value."); Wagner, supra note 10 , at 635 .

39 See American Law of Products Liability \$ 11:1 (John D. Hodson \& Charles J. Nagy, Jr. eds., $3 \mathrm{~d}$ rev. ed. 2005) (explaining that duty to test and inspect products is 
duty includes the duty to test for toxic risks associated with the use of chemical products. ${ }^{40}$ As the Third Restatement of Torts notes:

Of course, a seller bears responsibility to perform reasonable testing prior to marketing a product and to discover risks and risk-avoidance measures that such testing would reveal. A seller is charged with knowledge of what reasonable testing would reveal. If testing is not undertaken, or is performed in an inadequate manner, and this failure results in a defect that causes harm, the seller is subject to liability for harm caused by such defect. ${ }^{41}$

Numerous cases recognize the existence of a duty to test for hazards. ${ }^{42}$ In light of this duty, manufacturers are presumed to have the knowledge of an expert in the field and to be aware of reasonably foreseeable dangers. ${ }^{43}$ Under certain circumstances, a manufacturer may have a continuing duty to test for hazards after the sale of a prod-

an aspect of manufacturer's duty of reasonable care); Wagner, supra note 26, at 803-04 (describing duty "to resolve at least basic preventable scientific uncertainties prior to marketing a product").

40 See 72A C.J.S. Products Liability $\$ 112$ (2004) (stating that "manufacturer of a chemical, a dangerous product, is under a duty to exercise a high degree of care," which "includes the duty to inspect or test the chemical product").

41 Restatement (Third) of Torts: Products Liability $\$ 2$ (1998).

42 See Messer v. Amway Corp., 106 F. App'x 678, 686 (10th Cir. 2004) (recognizing duty to test under Kansas law); George v. Celotex Corp., 914 F.2d 26, 28 (2d Cir. 1990) (" $[\mathrm{A}]$ manufacturer has a duty to test fully and inspect its products to uncover all dangers that are scientifically discoverable."); Dartez v. Fibreboard Corp., 765 F.2d 456,461 (5th Cir. 1985) (holding, in products liability action, that asbestos manufacturers had "duty to fully test their products to uncover all scientifically discoverable dangers before the products are sold"); Borel v. Fibreboard Paper Prods. Corp., 493 F.2d 1076, 1090 (5th Cir. 1973); Kociemba v. G.D. Searle \& Co., 707 F. Supp. 1517, 1527 (D. Minn. 1989) ("[A] manufacturer has a duty to inspect and test its products."); Elam v. Lincoln Elec. Co., 841 N.E.2d 1037, 1043-45 (Ill. App. Ct. 2005) (upholding finding that defendants breached duty to investigate health hazards associated with welding); Owens-Corning Fiberglas Corp. v. Malone, 916 S.W.2d 551, 562 (Tex. App. 1996), aff' 972 S.W.2d 35 (Tex. 1998) (same); see also AMERICAN LAW of Products LiabilitT, supra note 39, $\$ 11: 8$ (noting manufacturer must conduct reasonable testing to demonstrate product's safety under conditions matching product's expected use).

43 See George, 914 F.2d at 28-29 (holding asbestos manufacturer could be charged with knowledge of adverse health effects based on what it "reasonably should have known had it either conducted its own tests or been in contact with others in the industry ... that were testing"); Borel, 493 F.2d at 1089; Valentine v. Baxter Healthcare Corp., 81 Cal. Rptr. 2d 252, 269 (Dist. Ct. App. 1999) (charging manufacturer "with the best scientific and medical knowledge, and with knowledge of substantial dangers involved in [product's] reasonably foreseeable use"); Owens-Corning, 916 S.W.2d at 562 (charging asbestos manufacturer with knowledge of discoverable dangers, including dangers known at time by other manufacturers). 
uct. ${ }^{44}$ And in some jurisdictions, manufacturers who conduct "state of the art" testing for toxic hazards may gain a complete defense to liability. ${ }^{45}$

\section{Difficulties in Enforcing the Duty to Test}

The duty to test for toxic hazards, however, is enforceable only if a plaintiff is injured and brings a cause of action against the manufacturer in strict liability, negligence, negligent failure to warn, or the like. ${ }^{46}$ Under existing law, the failure to test for toxic hazards cannot, by itself, serve as the basis for an independent cause of action. ${ }^{47}$ For many product liability cases, this is not a significant problem: plaintiffs injured by a defective tool or appliance typically will have little difficulty in identifying their injury and the manufacturer responsible for that injury. Plaintiffs in toxic tort cases, however, face numerous obstacles to bringing successful claims, particularly as to issues of causation.

Specifically, toxic tort plaintiffs must prove both general causation-that a substance is capable of causing the injury at issue-and specific causation-that exposure to the substance in fact caused the plaintiffs' injuries. ${ }^{48}$ Because of the extensive research required, the

44 See Kociemba, 707 F. Supp. at 1528 (holding that continuing duty to test exists where manufacturer has knowledge of problem with product, product is subject to continued sale or advertising, and where there was preexisting duty to warn of dangers associated with product).

45 See Wagner, supra note 26, at 794-95 (noting that "[s]tate-of-the-art testing generally consists of 'all of the available knowledge of a subject at a given time," including scientific, medical, engineering, and any other knowledge (quoting Lohrmann v. Pittsburgh Corning Corp., 782 F.2d 1156, 1164 (4th Cir. 1986))).

46 See Kociemba, 707 F. Supp. at 1527.

47 See Burton v. R.J. Reynolds Tobacco Co., 397 F.3d 906, 919-20 (10th Cir. 2005) (noting plaintiff must show failure to test and that such failure caused harm); Kociemba, 707 F. Supp. at 1528; Valentine, 81 Cal. Rptr. 2d at 265 (rejecting plaintiff's argument for independent duty to test); Vassallo v. Baxter Healthcare Corp., 696 N.E.2d 909, 921 (Mass. 1998) (" $[\mathrm{E}]$ vidence of failure adequately to test a product is relevant to claims of design, manufacturing, or warning defects, but does not furnish a separate, independent basis for liability."); Viguers v. Philip Morris USA, Inc., 837 A.2d 534, 541 (Pa. Super. Ct. 2003); Burley v. Kytec Innovative Sports Equip., Inc., 737 N.W.2d 397, $408 \&$ n.6 (S.D. 2007) (noting plaintiff must show failure to test and that such failure caused harm).

48 See Lin, supra note 15, at 1446-47. As Mark Geistfeld points out, a plaintiff can avoid some of the difficulties involving causation in products liability cases by alleging that a defendant manufacturer is liable for failing to warn that a product might be carcinogenic. See Geistfeld, supra note 19 , at 1018. Such warnings, even where toxicity data are inconclusive, "allow the user or consumer to avoid the risk warned against by making an informed decision not to purchase or use the product at all and hence 
probabilistic nature of research results, and the uncertainty often associated with those results, plaintiffs are rarely in a position to prove either general or specific causation. ${ }^{49}$ The manufacturer is often the only party with the knowledge and resources to do the necessary testing, but has little reason to generate the very evidence that plaintiffs might use against it. ${ }^{50}$ For manufacturers, ignorance about potential detrimental effects often represents a "willful, strategic choice."51 Compounding the difficulties of potential plaintiffs, certain claims may be available only to product users, and not to others exposed to toxins incidentally. ${ }^{52}$ Ultimately, placing the burden of proof of causation on toxic tort plaintiffs discourages manufacturers from producing toxicity information, encourages manufacturers to hinder thirdparty efforts to develop such information, and renders effective enforcement of the duty to test impossible.

not to encounter the risk." Id. at 1019 (quoting Restatement (ThiRd) of Torts: Products Liability $\$ 2 \mathrm{cmt}$. m. (1998)); $c f$. Restatement (Third) of Torts: ProdUCTS LIABILITY $\$ 2 \mathrm{cmt}$. $\mathrm{m}$ (noting seller of product must perform reasonable testing but is not liable for unforeseeable risks).

49 See Lin, supra note 15 , at 1446-47. There are a few decisions in favor of toxic tort plaintiffs notwithstanding weak evidence on causation. See Wagner, supra note 26, at 828-32. While these decisions have sometimes been cited as examples of the inability of judges and juries to handle complex scientific issues, Wendy Wagner instead characterizes these cases as examples of judge or jury nullification in which defendants are being held responsible for failing to conduct basic safety testing and thereby depriving plaintiffs of critical causation evidence. See id.

50 See Lyndon, supra note 30 , at 1817; Wagner, supra note 10 , at 636 ("When virtually no toxicity information is available on a chemical product, the manufacturer has little to fear from tort liability."). One commentator proposes to address this lack of evidence in the context of ongoing litigation by empowering courts in class actions to commission studies to determine general causation. See Kim, supra note 4, at 560 . This proposal might help to fill some of the information gaps in the limited number of cases where class certification is appropriate, but would do little to address the general problem of toxic ignorance.

51 Wagner, supra note 5, at 1638-39 (citing examples of Dalkon Shield, highabsorbency tampons, Bendectin, DES, breast implants, and tobacco); see also Wagner, supra note 26, at 775 (remarking that "it would be surprising if manufacturers ever conducted voluntary research on the long-term hazards of their products," in light of incentives generated by common law not to conduct toxicity research).

52 See Restatement (Second) of Torts § 402A caveat (1965) (expressing "no opinion" as to whether strict liability for defective products extends "to harm to persons other than users or consumers"); id. cmt. o (noting courts have generally denied recovery to casual bystanders and others who are neither users nor consumers). But see David G. Owen, Products Liability Law 266-67 (2005) (noting recent cases "have almost unanimously allowed foreseeable bystanders . . . to recover for their injuries caused by defective products"). 


\section{TSCA Makes Matters Worse}

Toxicity testing could be mandated by statute or as part of a regulatory regime. For most substances, however, existing regulatory mechanisms require no testing at all. Rather, as explained below, the current statutory scheme actually creates further disincentives for manufacturers to test.

The general authority to regulate chemical substances in the United States is found in the Toxic Substances Control Act ${ }^{53}$ (TSCA), which gives EPA broad authority to regulate the entire life cycle of a chemical substance-including the authority to order manufacturers to do the testing that would address the knowledge gap. ${ }^{54}$ TSCA applies to all chemicals other than those specifically exempted because of their coverage under other federal statutes. ${ }^{55}$ The statute provides EPA with regulatory authority in three key areas: regulating

53 Pub. L. No. 94469, 90 Stat. 2003 (1976) (codified as amended at 15 U.S.C. $\S \S 2601-2692(2006))$.

54 See Robert V. Percival et al., Environmental. Regulation 95 (5th ed. 2006) ("In theory, [TSCA] is the broadest source of EPA's regulatory authority . . . .").

55 See 15 U.S.C. $\$ 2602$ (2) (defining "chemical substance" to exclude pesticides, tobacco, nuclear material, food, food additives, drugs, cosmetics, and medical devices). Most of these exempted chemicals-pesticides and pharmaceuticals in particular-are subject to mandatory toxicity testing before they enter the stream of commerce. Under the Federal Insecticide, Fungicide, and Rodenticide Act (FIFRA), manufacturers must register a new pesticide with EPA before introducing it to the market. 7 U.S.C. $\$ 136$ a (2006 \& Supp. II 2008). Registration requires that an applicant demonstrate, through specified toxicological tests, that the product will not cause unreasonable harm and that it will perform its intended function without unreasonable harm. Id. $\$ 136 \mathrm{a}$ (c) (5); see 40 C.F.R. pt. 158 (2009). Pharmaceuticals are subject to an extensive premarket approval process administered by the Food and Drug Administration (FDA). 21 U.S.C. $\$ 355$ (2006). That process includes submission of an Investigational New Drug Application containing the results of pharmacological and toxicological studies and three phases of human clinical trials to determine effectiveness and toxicity. See 21 C.F.R. $\$ \S 312.20,312.23$ (2009) (clinical trials); id. $\$ \S 314.1-314.650$ (regulations governing approval of new drugs). Although the FDA also has authority to regulate cosmetics, it has interpreted that authority narrowly, placing the responsibility on cosmetic manufacturers to determine the safety of their own products before marketing. See Lin, supra note 13, at 373.

The regulatory regimes for pesticides and pharmaceuticals do ensure that at least some toxicity testing occurs. But as litigation against the manufacturers of Vioxx and Prozac illustrates, even these requirements hardly guarantee discovery of all serious health risks. See Berger \& Twerski, supra note 23, at 261 (commenting that safety studies done to obtain FDA approval often are inadequate to identify all toxic effects because of various factors, including their relatively short timeframe and small size); Wendy Wagner, When All Else Fails: Regulating Risky Products Through Tort Litigation, 95 GEO. L.J. 693, 711-12 (2007) (discussing role of pharmaceutical litigation in uncover- 
chemicals that present health or environmental risks, ${ }^{56}$ testing chemicals that are already in commerce but present unknown risks, ${ }^{57}$ and screening new chemicals and significant new uses of existing chemicals. ${ }^{58}$ Despite this seemingly broad authority, the vast majority of chemicals on the market have been subject to little or no testing. A closer examination of the provisions of TSCA and EPA practice under those provisions explains why.

\section{TSCA Does Not Require Toxicity Testing}

For chemicals already in commerce, section 4 of TSCA authorizes EPA to review potential health risks and to require manufacturers to conduct toxicity testing. TSCA, however, does not mandate that EPA undertake chemical risk reviews. Nor does TSCA impose on manufacturers a self-executing duty to conduct toxicity tests. Rather, EPA must first promulgate a rule before a manufacturer has the obligation to test a chemical. ${ }^{59}$ In the rule, EPA must establish that the chemical "may present an unreasonable risk of injury to health or the environment," 60 or that it "will be produced in substantial quantities" and result in "substantial human exposure" or entry of "substantial quantities" into the environment. ${ }^{61}$ Issuing test rules under section 4 has proven to be cumbersome: the process of finalizing such a rule may take two to ten years and cost hundreds of thousands of dollars. ${ }^{62}$ Since 1979, EPA has reviewed the safety of only two percent of the

ing hidden company documents and in raising public consciousness about misdeeds of drug companies).

56 Section 6 of TSCA authorizes EPA to regulate any chemical substance if it finds that there is a "reasonable basis to conclude" that such an activity "presents or will present an unreasonable risk of injury to health or the environment." 15 U.S.C. $\S 2605$ (a) (2006). This standard has proven difficult for EPA to meet. See Corrosion Proof Fittings v. EPA, 947 F.2d 1201, 1215-17, 1220, 1222 (5th Cir. 1991) (requiring EPA to balance cost of regulations against their benefits, to evaluate availability of substitutes for chemical in question, and to apply least burdensome regulatory measure that provides adequate protection).

57 See 15 U.S.C. $\$ 2603$ (2006).

58 See id. $\$ 2604$ (2006).

59 See id. \$2603(a).

60 See id. $\$ 2603(\mathrm{a})(1)(\mathrm{A})(\mathrm{i})$.

61 See id. § 2603(a) (1) (B) (i).

62 See GAO, Chemical Regulation, supra note 9, at 26; see also Applegate, supra note 26, at 315 (noting "elaborate procedures for development, promulgation, and judicial review" of test rules); Lyndon, supra note 30, at 1824 ("TSCA's use of strict rulemaking standards inhibits the very information production the statute was written to encourage."); Wagner, supra note 10, at 632 (describing Section 4 requirements as "a classic Catch-22" situation in which EPA must have some risk information in order to justify testing to determine risk). 
62,000 chemicals known to EPA at the time, and it has required testing for fewer than two hundred chemicals. ${ }^{63}$

New chemicals are subject to somewhat greater regulation, but hardly receive thorough scrutiny. Section 5 of TSCA requires manufacturers to provide a premanufacture notice (PMN) before beginning to manufacture a new chemical. ${ }^{64}$ Although EPA may take action to control unreasonable risks it identifies, manufacture of the chemical can proceed unless EPA acts on the PMN within ninety days. ${ }^{65}$ In filing a PMN, manufacturers must submit to EPA any test data in their possession or control related to health or environmental effects, as well as a description of any other toxicity data of which they are aware. ${ }^{66}$ TSCA, however, does not require that manufacturers generate such data in the first instance. ${ }^{67}$ Not surprisingly, most chemical companies do not perform toxicity testing voluntarily: only fifteen percent of PMNs contain health and safety test data. ${ }^{68}$ In the absence of such data, EPA relies heavily on analysis of structure activity relationships (SARs) to screen for and assess potential risks. This methodology involves the use of models to predict likely biological activity by comparing the molecular structure of new chemicals with the structure of chemicals with existing toxicity data. 69 While EPA believes that these models are effective as screening tools to identify chemicals meriting closer review, the agency admits that the overall accuracy of these models has not been validated. ${ }^{70}$

63 See GaO, Chemical Regulation, supra note 9, at 18.

6415 U.S.C. $\$ 2604$ (a). Section 5 of TSCA also gives EPA the authority to evaluate significant new uses of existing chemicals. Id. In order to determine that there is a significant new use, however, EPA must promulgate a rule pursuant to the Administrative Procedure Act. Id. $\$ 2604$ (a) (2). A company subject to such a rule must provide a significant new use notice (SNUN), which is similar to a PMN. See id.; Elizabeth C. Brown et al., Envtl. Law Inst., TSCA Deskbook 36-37 (1999).

65 See 15 U.S.C. $\$ \$ 2604(a)-(b)$. EPA takes no action on the vast majority of PMns. See John S. Applegate et al., The Regulation of Toxic Substances and HAZARDOUS WASTES 611 (2000); see also Applegate, supra note 5, at 1387 (describing PMN requirement as "relatively toothless").

6615 U.S.C. $\$ 2604$ (d) (1).

67 See id. $\$ 2604$; GAO, Chemical Regulation, supra note 9, at 10.

68 See GaO, Chemical Regulation, supra note 9, at 10-11 (reporting EPA estimate).

69 See id. at 11; Laura Robinson \& IAN Thorn, Toxicology and Ecotoxicology in Chemical Safety Assessment 123 (2005).

70 See GaO, Chemical. Regulation, supra note 9, at 12. But cf. Nat'l Research CoUncil, ToxicrTy Testing IN THE 21st CENTURY 99-100 (2007), ajailable at http:// www.nap.edu/catalog.php?record_id=11970 (describing successful applications of SAR analysis). Validation refers to the process by which the relevance and reliability of a test method are assessed for a particular purpose. See Michael Balls, International 


\section{TSCA Creates Disincentives to Test}

Not only does TSCA fail to require toxicity testing for either new or existing chemicals, but various provisions of the statute discourage manufacturers from conducting tests voluntarily. First, section 6 of TSCA imposes on EPA the burden of proving "an unreasonable risk of injury to health or the environment" as a prerequisite for regulation. ${ }^{71}$ This burden gives manufacturers a disincentive to produce risk information and an incentive to demand that EPA support any findings of risk with cost-benefit analysis and quantitative data. ${ }^{72}$ Voluntary testing is further discouraged by TSCA's requirement that manufacturers notify EPA of any information that "reasonably supports the conclusion that [the chemical] presents a substantial risk of injury to health or the environment . . ."73 Thus, a manufacturer who conducts extensive safety testing runs the risk of generating data to support regulation and of attracting scrutiny from plaintiffs' attorneys and regulators, with little potential marketing benefit. ${ }^{74}$

\section{The HPV Challenge Program Has Done Little to Bridge the Data Gap}

In an effort to shrink the toxics data gap, at least as to chemicals produced in large volumes, EPA and the chemical industry entered into a voluntary initiative, the High Production Volume Challenge Program. ${ }^{75}$ Under the program, chemical companies made commitments to "sponsor" HPV chemicals by making screening-level toxicity information available to the public. ${ }^{76}$ Sponsors pledged to propose and undertake test plans to develop data where screening information

Validation and Barriers to the Validation of Alternative Tests, in Alternatives to ANimal Testing 28, 28-29 (R.E. Hester \& R.M. Harrison eds., 2006).

7115 U.S.C. $\$ 2605$ (a) (2006); see supra note 56.

72 See Wagner, supra note 5, at 1682-87; Wagner, supra note 10, at 632 ; see also Applegate, supra note 5, at 1388 (discussing burdens placed on EPA by TSCA).

7315 U.S.C. $\$ 2607$ (e) (2006). This mandatory reporting requirement appears to have been ignored in numerous instances, as suggested by the fact that companies volunteered 11,000 studies of their products in response to a $1996 \mathrm{EPA}$ offer of substantially reduced penalties for noncompliance with that requirement. See Wagner, supra note 5 , at 1648 .

74 See Wagner, supra note 10 , at 630 ; see also Wagner, supra note 26 , at 820 ( $[\mathrm{T}]$ he manufacturing community appears to believe that safety research regarding latent harms invites, rather than wards off, litigation.").

75 See Data Collection and Development on High Production Volume (HPV) Chemicals, 65 Fed. Reg. 81,686, 81,692 (Dec. 26, 2000); David W. Case, The EPA's HPV Challenge Program: A Tort Liability Trap?, 62 WASH. \& LeE L. Rev. 147, 160-62 (2005).

76 See Case, supra note 75, at 160 . Screening-level information includes the minimum amount of data necessary to make an initial hazard assessment of a chemical. 
was unavailable. ${ }^{77}$ Announced in 1998, the program set a 2004 deadline for the final submission of data and a 2005 deadline for publication of the data. ${ }^{78}$

The results of the HPV Challenge have been mixed. Most of the chemicals on the list were sponsored, leaving only 265 unsponsored "orphan" chemicals. ${ }^{79}$ As of 2007 , however, EPA had received final submissions for only about half of the sponsored chemicals. ${ }^{80}$ In relatively few cases did sponsors develop new data; in most instances, sponsors relied on previously unpublished data or on alternative methods of estimating toxicity (such as quantitative SAR analysis). ${ }^{81}$ EPA itself has questioned whether the data produced by the program will be substantial enough to be used in risk assessment, suggesting that the data's utility may be limited to prioritizing chemicals for further study. ${ }^{82}$ Moreover, since the program's inception, hundreds of additional chemicals have reached HPV levels, and companies have agreed to sponsor less than half of these emerging HPV chemicals. ${ }^{83}$ Ultimately, the program has provided only a modest amount of data and has done nothing to change manufacturers' disincentives to perform toxicity research on their products. ${ }^{84}$

See EPA, Chfmical. Hazard Data, supra note 6, at 2. For more detail, see infra Part III.C.

77 See Case, supra note 75 , at $160-62$.

78 See id.

79 See Envtl. Def., High Hopes, Low Marks 11 (2007), available at http:// www.edf.org/documents/6653_HighHopesLowMarks.pdf (noting that of the 2782 HPV chemicals originally identified by EPA, 1899 were sponsored by industry, 425 were exempted or otherwise removed by EPA, 193 were sponsored under another program, and 265 were unsponsored).

80 See id. at 13.

81 See id. at 25; Kim, supra note 4, at 547.

82 See Sarah Bayko, Note, Reforming the Toxic Substances Control Act to Protect America's Most Precious Resource, 14 SE. ENVTL. L.J. 245, 273 (2006) ("EPA questions whether the data will prove substantial enough to use in risk assessments; the data may only help EPA with comparative risk analysis to prioritize chemicals that are of the most concern.").

83 See Envtl. Def., supra note 79, at 23.

84 See Case, supra note 75, at 196; Kim C. Lobring, Nanoscale Materials: Can (and Should) We Regulate the Next Industrial Revolution?, 2006 U. ILL. J.L. TECH. \& POL'y 313, 330 ("Unfortunately, the HPV Challenge Program does nothing to change a commercial participant's incentive to remain ignorant of the potential effects to health or the environment caused by their products."). 


\section{Articulating an Enforceable Duty to Test in Public Nuisance Doctrine}

As explained above, manufacturers of chemical substances have a duty under tort law to test those substances before introducing them into commerce or otherwise exposing the public to them. ${ }^{85}$ Anecdotal evidence suggests that the American public generally assumes that manufacturers carry out this duty and that chemicals in commerce have been tested for health, safety, and environmental effects. ${ }^{86}$ In fact, however, current testing efforts are grossly inadequate. For the various reasons just identified, the duty to test is rarely enforced, and the existing legal structure actually discourages manufacturers from performing the necessary tests. ${ }^{87}$

To address this failing, I propose the recognition of a new type of public nuisance for the failure to test chemical substances. This cause of action would be enforceable against manufacturers, processors, or importers of such substances. In contrast to conventional toxic tort litigation, however, no showing of physical injury would be required. Rather, the failure to test itself constitutes a public nuisance because that failure puts the public health at risk and because the resultant lack of information undermines the ability of governments and individuals to protect public health. This Part explains the legal foundation for this cause of action.

\section{A. Public Nuisance Doctrine}

Originating in common law criminal prosecutions by the King to address encroachments upon the royal domain, public nuisance is

85 See supra Part I.C.1.

86 See Cranor, supra note 25, at 310 (noting some citizens feel "surprised" when they learn about the presence of industrial chemicals in their bodies); Wagner, supra note 26, at 784 ("Consumers appear to assume that most products are safe, regardless of the presence or absence of costly research programs."); Cambridge Reports, National Omnibus Survey, Dec. 1994, available at http://www.ropercenter.uconn. edu/ipoll.html (reporting 55\% of respondents answered "yes" and $38 \%$ answered "no" in response to survey asking whether "the chemical industry does a good job in trying to protect consumers from the possible chemical risks of their products"); Cambridge Reports, National Omnibus Survey, Dec. 1993, available at http://www.roper center.uconn.edu/ipoll.html (reporting two-thirds of respondents disagreed with statement that " $[\mathrm{w}] \mathrm{e}$ should assume a chemical is safe unless tests prove it to be dangerous").

87 See supra Parts I.C.2, I.D.2. 
more commonly a source of civil tort liability today. ${ }^{88}$ The quasi-criminal nature of the tort of public nuisance nevertheless is reflected in one commentator's remark that "the sovereign's suit against a nuisance is not a tort action, but an exercise of the police power." 89 This power is a broad one, with public nuisance encompassing any "unreasonable interference with a right common to the general public."90

Public nuisance includes a wide variety of conduct ranging from actions harmful to public health to behavior deemed damaging to public morals. ${ }^{91}$ Plaintiffs have asserted public nuisance claims successfully in response to various environmental problems, including dust, smoke, noise, odors, and releases of hazardous chemicals. ${ }^{92}$ Attempts to apply public nuisance theory in recent environmental litigation include actions against automobile manufacturers and operators of coal-fired power plants to reduce greenhouse gas emissions, as well as actions against lead paint companies to recoup the cost of lead abatement. $^{93}$ Given the breadth of conduct that might fall within its

88 See Donald G. Gifford, Public Nuisance as a Mass Products Liability Tort, 71 U. CiN. L. REV. 741, 790-809 (2003) (providing a historical account of the development of public nuisance doctrine).

89 See Louise A. Halper, Public Nuisance and Public Plaintiffs: Rediscovering the Common Law (Part I), 16 ENVTL. L. Rep. 10,292, 10,292 (1986).

90 Restatement (Second) of ToRTs $§ 821 \mathrm{~B}(1)$ \& cmt. a (1979).

91 See William L. Prosser, Private Action for Public Nuisance, 52 VA. L. Rev. 997, 999 (1966) (describing public nuisance as a species of catch-all low-grade criminal offense, consisting of an interference with the rights of the community at large, which may include anything from the blocking of a highway to a gaming-house or indecent exposure").

92 Restatement (Second) of Torts $§ 821$ B cmt. b (1979); Denise E. Antolini \& Clifford L. Rechtschaffen, Common Law Remedies: A Refresher, 38 ENVTL. L. REP. 10,114, 10,120-21 (2008) (listing examples of circumstances in which environmental harms have been found to be public nuisances). In contrast to private nuisance, public nuisance does not require proof of interference with use and enjoyment of land. See Restatement (Second) of Torts $\$ 821 \mathrm{~B}$ cmt. h; Antolini \& Rechtschaffen, supra, at 10,120 .

93 See Matthew F. Pawa, Global Warming: The Ulitmate Public Nuisance, in Creatrve Common Law Strategies for Protecting The Environment 107 (Clifford Rechtschaffen \& Denise Antolini eds., 2007) [hereinafter Creatrve Common Law StrateGIEs]; Katie J. Zoglin, Getting the Lead Out: The Potential of Public Nuisance in Lead-Based Paint Litigation, in Creative Common Law Strategies, supra, at 339. District courts initially dismissed the climate change public nuisance claims on political question grounds. See California v. Gen. Motors Corp., No. C06-05755, 2007 WL 2726871, at *16 (N.D. Cal. Sept. 17, 2007); Connecticut v. Am. Elec. Power Co., 406 F. Supp. 2d 265, 274 (S.D.N.Y. 2005), vacated 582 F.3d 309 (2d Cir. 2009). Two recent court of appeals decisions, however, allowed such claims to go forward. See Comer v. Murphy Oil USA, 585 F.3d 855, 859-60 (5th Cir. 2009); Connecticut v. Am. Elec. Power Co. 582 F.3d 309, 315 (2d Cir. 2009). 
scope, it is not surprising that efforts to apply public nuisance doctrine in mass products liability cases against handgun manufacturers and tobacco companies have fueled criticism of the doctrine as lacking meaningful boundaries. ${ }^{94}$

So what exactly must be proven to demonstrate a public nuisance? Confusion has sometimes surrounded the definition of public nuisance, and the contours of the doctrine vary by state. ${ }^{95}$ The term "public nuisance" sometimes refers to conduct that creates an unreasonable interference with a public right, and at other times refers to the resulting harm or damages suffered by the public at large. ${ }^{96}$ Notwithstanding such discrepancies, the basic elements of a public nuisance claim can be distilled into the following elements: (1) an unreasonable and substantial interference (2) with a public right (3) where the defendant has control of the instrumentality causing the nuisance. ${ }^{97}$ Courts and commentators are divided over the role of fault, with some requiring that the defendant's conduct be intentional, unreasonable, violative of a statute, or otherwise tortious; and others holding that liability for public nuisance is strict. ${ }^{98}$

94 See, e.g., Gifford, supra note 88 , at 834 (contending that public nuisance should not be a means of recovering damages from product manufacturers).

95 See Robert Abrams \& Val Washington, The Misunderstood Law of Public Nuisance: A Comparison with Private Nuisance Twenty Years After Boomer, 54 ALB. L. REv. 359, 359 (1990); Gifford, supra note 88, at 774-75 (noting public nuisance's lack of meaningful definition and discernible boundaries).

96 See Gifford, supra note 88, at 779-80 (discussing courts' different understandings of the term).

97 See Dan B. DobBs, The LAW of Torts 1334 (2000) (defining public nuisance as "a substantial and unreasonable interference with a right held in common by the general public, in use of public facilities, in health, safety, and convenience"); Abrams \& Washington, supra note 95, at 374-75; Gifford, supra note 88, at 813-30 (outlining "fundamental principles" governing public nuisance).

Although some definitions of public nuisance, including that found in the Second Restatement of Torts, do not explicitly demand that the defendant be in control of the instrumentality causing the nuisance, see RESTATEMENT (SECOND) OF TORTS $\$ 821 \mathrm{~B}$, a majority of courts have continued to look for this traditional element. See, e.g., Camden County Bd. of Chosen Freeholders v. Beretta, U.S.A. Corp., 273 F.3d 536, 539 (3d Cir. 2001) (discussing public nuisance under New Jersey law); State v. Lead Indus. Ass'n, 951 A.2d 428, 446 (R.I. 2008); Gifford, supra note 88, at 820-21 n.394 (citing cases); Victor E. Schwartz \& Phil Goldberg, The Law of Public Nuisance: Maintaining Rational Boundaries on a Rational Tort, 45 WASHBURN L.J. 541, 567-68 (2006) (discussing cases). But cf. In re Lead Paint Litig., 924 A.2d 484, 510-11 (N.J. 2007) (Zazzali, C.J., dissenting) (citing cases that reject control requirement).

98 Compare, e.g., City of Cincinnati v. Beretta U.S.A. Corp., 768 N.E.2d 1136, 1143 n.4 (Ohio 2002) (requiring negligence, intent, or unlawful activity), RESTATEMENT (SECOND) OF TORTS $\$ 821 \mathrm{~B} \mathrm{cmt.} \mathrm{e} \mathrm{("}[T]$ he defendant is held liable for a public nuisance if his interference with the public right was intentional or was unintentional 
In addition, public nuisance claims traditionally have been subject to two important limitations. First, only public authorities could bring such claims, a feature that reflected the doctrine's common law roots in criminal proceedings. ${ }^{99}$ Second, public authorities generally could obtain only injunctive relief when bringing a civil public nuisance action. ${ }^{100}$ Modern precedents have relaxed these limitations to some degree. Private plaintiffs may bring public nuisance claims if they have suffered a "special injury"-an injury different in kind from the public's general injury. ${ }^{101}$ And some courts allow public authorities to recover damages in public nuisance actions under the theory that the state is acting as a "quasi-sovereign" in a parens patriae action. ${ }^{102}$ The following paragraphs consider the basic elements of public nuisance in further detail.

and otherwise actionable under the principles controlling liability for negligent or reckless conduct or for abnormally dangerous activities."), and Gifford, supra note 88, at 828-30 (contending failure to require fault "invites the court and jury to find a public nuisance without guidance and standards"), with New York v. Shore Realty Corp., 759 F.2d 1032, 1051 (2d Cir. 1985) (rejecting landowner's claim that other parties were responsible for chemical contamination on property and explaining that one can be "liable for maintenance of a public nuisance irrespective of negligence or fault"), Abrams \& Washington, supra note 95, at 368 ("[T] he application of fault principles is certainly erroneous; the standard of liability in a public nuisance action is strict."), and Halper, supra note 89, at 10,294 ("[I]t does not matter with what degree of care one hinders the exercise of common public rights .... If [they] are hindered, whether willfully, recklessly, or carelessly, the nuisance must be abated . . . .").

99 See Gifford, supra note 88, at 814.

100 See Abrams \& Washington, supra note 95, at 379; Gifford, supra note 88, at 814 ("The core concept behind public nuisance is the right of public authorities to end defendant's conduct that harms the public, through remedies of either injunctive relief or criminal prosecution."); see also In re Lead Paint Litig., 924 A.2d at 498-99 (contending that public plaintiff asserting public nuisance claim is limited to remedies of abatement and recovery of costs of abatement, in contrast to private plaintiff, who can sue for damages caused by public nuisance if he can demonstrate special injury). Gifford further notes that " $[\mathrm{h}]$ istorically, the recovery of damages has been an ancillary and unusual remedy when a public nuisance was found to exist." Gifford, supra note 88, at 814 . But see 58 AM. JuR. 2D Nuisance $\$ 31$ (2002) ("Both private and public nuisances are actionable either for their abatement or for damages, or both."). 101 See Restatement (Second) of TorTs $\$$ 821C; DobBs, supra note 97, at 1335; Gifford, supra note 88, at 814. See generally Denise E. Antolini, Modernizing Public Nuisance: Solving the Paradox of the Special Injury Rule, 28 Ecolocy L.Q. 755 (2001) (proposing an "actual community injury" standard to revitalize public nuisance as a broad remedy).

102 See Antolini \& Rechtschaffen, supra note 92, at 10,120; Gifford, supra note 88, at 784 . 
Public nuisance encompasses "interference with public rights." 103 What exactly is a "public right" for purposes of public nuisance doctrine? The Second Restatement of Torts describes a public right as "one common to all members of the general public" and "collective in nature." 104 Such a right can be distinguished from the "individual right that everyone has not to be assaulted or defamed or defrauded or negligently injured." 105 In other words, for a public right to be violated, there must be more than an aggregation of private rights violations. ${ }^{106}$ A public nuisance involves an act "that could hurt any member of the public, not just a plaintiff situated in circumstances unique to an individual or subsection of the general public."107 Public rights thus include common law rights in health, safety, and comfort-such as the right to unobstructed highways and waterways and the right to unpolluted air and water-as well as rights identified by statute. ${ }^{108}$ Attempting to distill the various situations in which public nuisance doctrine has been applied, the Wisconsin Supreme Court has suggested that public nuisance involves interference "with the use

103 See Antolini \& Rechtschaffen, supra note 92, at 10,120 ("The interference need not be related to land, but can be much broader, affecting virtually any public resource or place."). Public nuisance thus stands in direct contrast to private nuisance, which requires interference with the enjoyment of private property. See DobBs, supra note 97, at 1335; Abrams \& Washington, supra note 95, at 364.

104 Restatement (SECOND) OF Torts $\$ 821 \mathrm{~B} \mathrm{cmt.} \mathrm{g.}$

105 Id

106 See State v. Lead Indus. Ass'n, 951 A.2d 428, 448 (R.I. 2008); Gifford, supra note 88, at 817. But cf. Restatement (SECOND) OF ToRTs $\$ 821 \mathrm{~B} \mathrm{cmt.} \mathrm{g} \mathrm{(noting} \mathrm{that}$ "no public right as such need be involved" in those states where public nuisance is defined to include interference with "any considerable number of persons").

107 Adams v. City of W. Hartford, No. CV0640271 10, 2008 WL 4253413, at *6-7 (Conn. Super. Ct. Aug. 28, 2008) (holding that child injured in public school could not assert public nuisance claim); Gifford, supra note 88 , at 818 (questioning whether injuries suffered in private home could be subject to public nuisance claim).

108 See Lead Indus. Ass'n, 951 A.2d at 453 (describing public right); DosBs, supra note 97, at 1335; Gifford, supra note 88 , at 815 (describing fact patterns constituting public nuisance under common law). California, for example, defines a nuisance as:

Anything which is injurious to health, including, but not limited to, the illegal sale of controlled substances, or is indecent or offensive to the senses, or an obstruction to the free use of property, so as to interfere with the comfortable enjoyment of life or property, or unlawfully obstructs the free passage or use, in the customary manner, of any navigable lake, or river, bay, stream, canal, or basin, or any public park, square, street, or highway . . .

Cal. Crv. Code $\$ 3479$ (West 1997). Public nuisance is defined as "[a nuisance] which affects at the same time an entire community or neighborhood, or any considerable number of persons, although the extent of the annoyance or damage inflicted upon individuals may be unequal.” Id. $\S 3480$. 
of a public place or with the activities of an entire community."109 While the public rights that fall within the protection of public nuisance doctrine are broad in scope, they are not limitless. Contrasting "public right" with the broader concept of "public interest," Donald Gifford contends that "while it is in the public interest to promote the health and well-being of citizens generally, there is no common law public right to a certain standard of medical care or housing." 110 These concerns, Gifford suggests, do not involve interference with use of a public place or with activities of an entire community. ${ }^{111}$

The interference with public rights must be substantial (i.e., significant) and unreasonable in order to be a public nuisance. ${ }^{112}$ Significance requires that the harm complained of be more than trivial, although the mere threat of substantial harm will suffice. ${ }^{13}$ The requirements of significance and unreasonableness essentially overlap, as section $821 \mathrm{~B}$ of the Second Restatement of Torts suggests. Section $821 \mathrm{~B}$ lists various circumstances that may sustain a finding that interference with a public right is unreasonable:

(a) Whether the conduct involves a significant interference with the public health, the public safety, the public peace, the public comfort or the public convenience, or

(b) whether the conduct is proscribed by a statute, ordinance or administrative regulation, or

(c) whether the conduct is of a continuing nature or has produced a permanent or long-lasting effect, and, as the actor knows or has reason to know, has a significant effect upon the public right. ${ }^{114}$

Reasonability turns on the significance of the interference, as in the first and third Restatement examples, or on a prior legislative or administrative judgment of unreasonability akin to per se negligence, as in

109 Gifford, supra note 88, at 815 (quoting Physicians Plus Ins. Corp. v. Midwest Mut. Ins. Co., 646 N.W.2d 777, 788 (Wis. 2002)).

110 Gifford, supra note 88, at 815. But of. James L. Huffman, Beware of Greens in Praise of the Common Law, 58 CASE W. Res. L. Rev. 813, 826-27 (2008) (suggesting that "the concept of public rights . . . is more than elusive of definition" and that "public rights' is just another term for public interest").

111 Gifford, supra note 88, at 815 . In contrast, Gifford concedes that persons sickened by exposure to secondhand smoke in public places-a situation analogous to exposure to untested chemicals-could conceivably demonstrate interference with a public right. Id. at 817 .

112 See Abrams \& Washington, supra note 95, at 374.

113 Id.

114 Restatement (Second) of Torts $\$ 821$ B (1979); see also Dobbs, supra note 97, at 1334 (defining public nuisance as "a substantial and unreasonable interference with a right held in common by the general public, in use of public facilities, in health, safety, and convenience"). 
the second example. ${ }^{115}$ Note, moreover, that this inquiry into "reasonability" is not concerned with whether the actor's conduct was negligent, but rather focuses on the resulting interference with public rights. Consistent with this view, Donald Gifford has suggested that courts should consider the following factors in determining whether interference is unreasonable: "(i) the number of people susceptible, (ii) the degree of risk of harm occurring, (iii) the duration of the risk of harm occurring, and (iv) the severity of the harm that may occur." 116 In contrast to private nuisance, where the reasonableness inquiry calls for a weighing of the gravity of the harm to the plaintiff against the utility of the defendant's conduct, ${ }^{117}$ public nuisance involves no such balancing of the utilities. ${ }^{118}$

Many courts also require as an element of public nuisance that the defendant have control of the instrumentality causing the nuisance. ${ }^{119}$ This element is rooted in the historical use of public nuisance by the state to enjoin conduct injuring the public health, safety, or welfare. ${ }^{120}$ A defendant who no longer exercises possession or control, the reasoning goes, is not in position to abate a nuisance. ${ }^{121}$ The requirement of control has proven fatal to most attempts to apply public nuisance doctrine against product manufacturers, including makers of handguns and lead paint. ${ }^{122}$ In the handgun cases, states alleged that handgun manufacturers created a public nuisance by making handguns readily available and sought compensation for expenses incurred in responding to handgun violence. ${ }^{123}$ In the lead

115 See Restatement (Second) of Torts $\$ 821 \mathrm{~B} \mathrm{cmt.} \mathrm{e.}$

116 Gifford, supra note 88, at 816.

117 See Restatement (SeCOND) of Torts $\$ 826$.

118 See Abrams \& Washington, supra note 95, at 376-78 (arguing that commentary suggesting that balancing of utilities test should apply to public nuisance claims is impractical and contrary to precedent); see also Georgia v. Tenn. Copper Co., 206 U.S. 230, 238-39 (1907) (rejecting balancing of utilities in granting injunction to State of Georgia against air pollution generated by defendant based on finding of public nuisance).

119 See supra note 97.

120 See Gifford, supra note 88, at 819-20.

121 See, e.g., State v. Lead Indus. Ass'n, 951 A.2d 428, 449 (R.I. 2008) ("The party in control of the instrumentality causing the alleged nuisance is best positioned to abate it and, therefore, is legally responsible.").

122 The issue of control is sometimes subsumed within a requirement of causation. See, e.g., City of Chi. v. Beretta U.S.A. Corp., 821 N.E.2d 1099, 1132 (Ill. 2004) (characterizing control as "a relevant factor in both the proximate cause inquiry and in the ability of the court to fashion appropriate injunctive relief").

123 See, e.g., Camden County Bd. of Chosen Freeholders v. Beretta, U.S.A. Corp., 273 F.3d 536, 538-39 (3d Cir. 2001) ("The County alleges that the manufacturers' conduct ... imposed inordinate financial burdens on the County's fisc."); City of Chi., 
paint litigation, states sought damages from paint manufacturers as well as abatement of lead paint in residences. ${ }^{124}$ A number of courts have rejected public nuisance claims in these contexts on the ground that the respective manufacturers were no longer in control of the instrumentality causing the nuisance and thus had no ability to abate the nuisance. ${ }^{125}$

Some jurisdictions confronted with public nuisance claims against product manufacturers interpret the control element more loosely, however. ${ }^{126}$ Rather than requiring control, these courts hold that a defendant manufacturer's acts or omissions need only be a substantial factor with respect to the harm suffered in order for the defendant to be liable under public nuisance. ${ }^{127}$ Such decisions recognize that a manufacturer should be held responsible for the consequences of its actions, even if those consequences are somewhat removed from the manufacturer. ${ }^{128}$

Finally, as noted above, courts are divided over whether fault is necessary to demonstrate a public nuisance. ${ }^{129}$ Requiring such a showing is inconsistent with the common law examples of nuisance, which concern themselves primarily with redressing the interference with a public right, rather than with judging the moral culpability of a

821 N.E.2d at 1107-09 (describing the City's complaint including assertions that the dealers' practices had caused a large underground market for illegal firearms to flourish).

124 In re Lead Paint Litig., 924 A.2d 484, 486-87 (N.J. 2007); Lead Indus. Ass'n, 951 A.2d at 440 .

125 See, e.g., City of Phila. v. Beretta U.S.A. Corp., 277 F.3d 415, 422 (3d Cir. 2002) (deciding under Pennsylvania law that gun manufacturers were not liable because of lack of control); Camden County, 273 F.3d at 541-42 (affirming dismissal of public nuisance claim against gun manufacturers under New Jersey law); In re Lead Paint Litig., 924 A.2d at 501 (rejecting public nuisance claims against lead paint manufacturers because such theory would "eliminate entirely the concept of control of the nuisance"); Lead Indus. Ass'n, 951 A.2d at 455 (holding that public nuisance claims against lead paint manufacturers should have been dismissed); see also Gifford, supra note 88 , at 822 (contending that in such cases, "[ $t]$ he harm or injurious condition allegedly created by the public nuisance clearly is not within the control of the defendants").

126 See Ileto v. Glock Inc., 349 F.3d 1191, 1212 (9th Cir. 2003); City of Cincinnati v. Beretta U.S.A. Corp., 768 N.E.2d 1136, 1143 (Ohio 2002) (rejecting gun manufacturer's contention that lack of control of firearms at moment of harm barred liability under public nuisance); Northridge Co. v. W.R. Grace \& Co., 556 N.W.2d 345, 351-52 (Wis. Ct. App. 1996) (holding asbestos manufacturers liable under public nuisance theory).

127 See lleto, 349 F.3d at 1212; City of Cincinnati, 768 N.E.2d at 1143.

128 See Ileto, 349 F.3d at 1212-13; City of Cincinnati, 768 N.E.2d at 1143.

129 See supra note 98 and accompanying text. 
defendant's conduct. ${ }^{130}$ As one commentator has contended, " $[\mathrm{t}]$ he public should not be made to suffer an unreasonable interference with its rights merely because the entity responsible for the interference is acting non-negligently and without bad intent."131

\section{B. Applying Public Nuisance Doctrine to the Failure to Test}

Do the "rights common to the general public" and subject to protection against interference through a public nuisance action extend to a right not to be exposed to untested or inadequately tested chemical substances? In other words, can public nuisance doctrine encompass a company's failure to test the chemicals it manufactures before releasing them into the stream of commerce? Even though application of public nuisance in such situations would represent an extension beyond common law precedents, consideration of the scope, purpose, and origins of the public nuisance doctrine suggests an affirmative answer.

As discussed above, public nuisance essentially involves interference with public rights. The public rights that a state may protect via public nuisance include the collective interests of its citizens in the quality of the state's environment, a point illustrated by Georgia v. Tennessee Copper Co., ${ }^{132}$ one of the Supreme Court's leading decisions on public nuisance. In that case, Georgia sought to enjoin out-of-state copper companies from discharging pollutants that were allegedly damaging forests and crops within the state of Georgia. ${ }^{133}$ Noting that the case involved "a suit by a State for an injury to it in its capacity of quasi-sovereign," the Court observed that "[i]n that capacity the State has an interest independent of and behind the titles of its citizens, in all the earth and air within its domain. It has the last word as to whether its mountains shall be stripped of their forests and its inhabitants shall breathe pure air."134 Tennessee Copper is instructive on at least two important points. First, the decision underscores that the state's police power is the basis for public nuisance actions brought by

130 See, e.g., Commonwealth v. Barnes \& Tucker Co., 319 A.2d 871, 883, 885 (Pa. 1974) (finding that acid mine drainage discharging from mine constituted public nuisance and explaining that " $[t]$ he absence of facts supporting concepts of negligence, foreseeability or unlawful conduct is not in the least fatal to a finding of the existence of a common law public nuisance").

131 Abrams \& Washington, supra note 95, at 370.

132206 U.S. 230 (1907).

$133 I d$. at 236.

$134 I d$. at 237. See also Missouri v. Illinois, 180 U.S. 208, 241 (1901) ("[I]f the health and comfort of the inhabitants of a State are threatened, the State is the proper party to represent and defend them."). 
a public entity. Public nuisance thus is quite distinct from private nuisance in its origins as well as in the scope of interests it seeks to protect. ${ }^{135}$ Acting as parens patriae, the state may bring public nuisance actions to protect the health and welfare of its citizens. ${ }^{136}$ Second, Tennessee Copper affirms the breadth of the power that the state can effectuate through public nuisance actions. Rejecting the defendants' argument that the harm to the state had to be balanced against the economic benefit of the copper smelting operations, the Court char. acterized the state's quasi-sovereign authority in these matters as virtually absolute:

Whether Georgia by insisting upon this claim is doing more harm than good to her own citizens is for her to determine. The possible disaster to those outside the State must be accepted as a consequence of her standing upon her extreme rights. ${ }^{137}$

Admittedly, the failure to undertake testing to determine health and safety risks differs from the palpable harm of Tennessee Copper and familiar examples of interferences with public health or comfortsmoke, noise, and the like-that constituted public nuisances under the common law. The modern understanding of "interference with public rights," however, is broader than the limited conception of nuisance as a tangible harm or annoyance. ${ }^{138}$ First, public nuisance has

135 Cf. People ex rel. Gallo v. Acuna, 929 P.2d 596, 603 (Cal. 1997) ("Unlike the private nuisance-tied to and designed to vindicate individual ownership interests in land-the 'common' or public nuisance emerged from distinctly different historical origins. The public nuisance doctrine is aimed at the protection and redress of community interests and, at least in theory, embodies a kind of collective ideal of civil life which the courts have vindicated by equitable remedies since the beginning of the 16th century.").

136 See Alfred L. Snapp \& Son, Inc. v. P.R. ex rel. Barez, 458 U.S. 592, 600-07 (1982) (noting that parens patriae, literally meaning "parent of the country," refers to authority of the state to litigate to defend quasi-sovereign interests, including health and wellbeing of its residents).

137 Tennessee Copper, 206 U.S. at 239. The Court recently reaffirmed these principles in Massachusetts $v$. EPA, a successful challenge by several states to EPA's refusal to regulate greenhouse gas emissions from new motor vehicles under Section 202 of the Clean Air Act. See Massachusetts v. EPA, 549 U.S. 497 (2007). Discussing whether the states had standing to sue, the Court cited Tennessee Copper for the proposition that states have standing "to litigate as parens patriae to protect quasi-sovereign interestsi.e., public or governmental interests that concern the state as a whole." Id. at 520 n.17. Although the Supreme Court has declined to set out an exhaustive definition of quasi-sovereign interests, it has made clear that "a State has a quasi-sovereign interest in the health and well-being-both physical and economic-of its residents in general." Snapp E' Son, Inc., 458 U.S. at 607.

138 See Prosser, supra note 91, at 997 (noting that "[ $n]$ uisance is a French word which means nothing more than harm"). 
not been confined to situations where plaintiffs have suffered tangible injury. Interference with the public peace, as by loud noises, and interference with public morals, as in cases of prostitution, were recognized as public nuisances by the common law. ${ }^{139}$ Indeed, the Second Restatement of Torts identifies five broad categories of public rights subject to protection through a public nuisance action: "the public health, the public safety, the public peace, the public comfort [and] the public convenience." 140 Not surprisingly, the mere risk of harm has long been sufficient to establish a public nuisance, ${ }^{141}$ as demonstrated by common law cases involving the keeping of diseased animals, the maintenance of a pond breeding malarial mosquitoes, and the storage of explosives in the midst of a city. ${ }^{142}$ A state's quasi-sovereign interests "in the well-being of its populace" 143 readily extend beyond these situations and include protection against potential injury from exposure to untested chemicals. ${ }^{144}$

Untested chemicals do present a somewhat more complicated situation than the above-noted examples of public nuisance in that the risk of injury is not established for individual substances. More specifically, while we have a sound basis for believing that untested substances collectively pose a significant threat to public health, there is almost no way of knowing which individual chemicals do so without testing-testing that the manufacturer is in the best position to perform. Absent testing, chemical manufacturers are imposing uncertain risks on consumers and on the public at large. Although the law typically has not recognized such uncertainty as harm per se, ${ }^{145}$ the public

139 See Restatement (Second) of Torts $\$ 821 \mathrm{~B} \mathrm{cmt.} \mathrm{b} \mathrm{(1979);} \mathrm{e.g.,} \mathrm{Price} \mathrm{v.} \mathrm{State,}$ 600 N.E.2d 103 (Ind. Ct. App. 1992) (discussing common law prohibition on noise); City of N.Y. ex rel. People v. Taliaferrow, 544 N.Y.S.2d 273, 275-76 (Sup. Ct. 1989) (discussing prostitution as a public nuisance).

140 Restatement (Second) of Torts $§ 821 \mathrm{~B}(2)$ (a).

141 See Mugler v. Kansas, 123 U.S. 623, 673 (1887) ("[Courts of equity] can not only prevent nuisances that are threatened, and before irreparable mischief ensues, but arrest or abate those in progress, and, by perpetual injunction, protect the public against them in the future ... ."); Abrams \& Washington, supra note 95, at 374 ( $[\mathrm{T}]$ he harm need not even be actual if the threat of harm is great enough.").

142 Restatement (Second) of Torts $\$ 821 \mathrm{~B} \mathrm{cmt}$. b.

143 Alfred L. Snapp \& Son, Inc. v. P.R. ex rel. Barez, 458 U.S. 592, 602 (1982).

144 Cf. Allan Kanner, The Public Trust Doctrine, Parens Patriae, and the Attorney General as the Guardian of the State's Natural Resources, 16 Duke ENvTL. L. \& PoL'y F. 57, 109 (2005) (listing examples of threats to public health, safety, and welfare where courts have recognized states' authority to sue as parens patriae).

145 See Lin, supra note 3, at 975 (explaining that concept of harm reflects community's normative judgments regarding significant setbacks to one's interests); see also Claire Finkelstein, Is Risk a Harm?, 151 U. PA. L. Rev. 963, 970-73 (2003) (contending that persons subjected to risks, even if no physical harm comes to pass, have neverthe- 
right to unpolluted air and water, which undoubtedly includes a right to protect the public against exposure to substances known to be harmful, also should encompass a right to protect the public against exposure to untested substances. Such exposure is problematic not only because of its potential to interfere with the public health and the environment, but also because it runs afoul of principles of personal autonomy and valid consent. ${ }^{146}$ These principles, which are implicated by matters involving "the integrity of [an] individual's own projects and self-conception," particularly "the use made of one's own body," 147 are denigrated whenever the public is exposed to untested chemicals. ${ }^{148}$ Even absent proof of physical harm or causation, such exposure deprives the public of its ability to choose whether or not to be exposed to an untested product. ${ }^{149}$

Application of public nuisance in these circumstances would be consistent with the origins of public nuisance doctrine in the state's

less suffered harm); Glen O. Robinson, Probabilistic Causation and Compensation for Tortious Risk, 14 J. Legal Stud. 779, 783 (1985) (proposing liability based upon creation of risk of injury).

146 See E. Donald Elliott, The Future of Toxic Torts: Of Chemophobia, Risk as a Compensable Injury and Hybrid Compensation Systems, 25 Hous. L. Rev. 781, 789 (1988) (contending that " $[t]$ he violation of a person's bodily autonomy . . . that occurs when one is assaulted with a potentially hazardous chemical[ ] is . . . an injury that the law should recognize and compensate"); Clifford Rechtschaffen, Advancing Environmental Justice Norms, 37 U.C. Davis L. Rev. 95, 112-13 (2003); see also Berger \& Twerski, supra note 23, at 259 (arguing for right of patients to informed choice about a drug's risks and for enforceability of such right without having to prove that drug caused plaintiffs' harms).

147 Peter H. Schuck, Rethinking Informed Consent, 103 YALE L.J. 899, 924 (1994).

148 See Berger \& Twerski, supra note 23, at 273 ("[T] he denial of the right to choose not to expose onself to an uncertain risk violates a very basic human right of autonomous decisionmaking. ..."); cf. Cranor, supra note 25, at 283 ("Under postmarket laws the American citizenry are, in effect, human guinea pigs for the commercial creations of American industry."). The importance of bodily autonomy is reflected in its protection through individual torts such as assault and battery. $C f$. id. at 300-01 ("Morally, citizens should regard invasion of their bodies without permission by humanly created substances as a trespass.").

$149 C f$. Berger \& Twerski, supra note 23, at 274 ("If indeed there is a right to informed choice, conditioning the right on proof that the harm was actually brought about by the defendant's conduct makes no sense whatsoever. If an uncertain risk of harm should have been communicated to the plaintiff so that the plaintiff could assess whether she wished to play this game of russian roulette, to then say that the plaintiff is not entitled to recovery because she cannot prove that the harm was actually caused by the suspect drug, renders the right to informed choice illusory."). 
police power. ${ }^{150}$ The police power, commonly described as the power to protect public health, safety, morals, and general welfare, ${ }^{151} \mathrm{com}$ prehends the authority to enact legislation to prevent environmental pollution and to abate public nuisances. ${ }^{152}$ This power is the "least limitable" of all state powers and may be exercised broadly as long as its exercise is not arbitrary. ${ }^{153}$ Although states generally have not taken a precautionary approach to chemical regulation by requiring proof of safety as a condition of manufacture or distribution, ${ }^{154}$ there is no doubt that the police power extends to the authority to regulate-and even prohibit-untested chemical substances that may be harmful to public health or that may pollute the environment. ${ }^{155}$ This understanding of the police power supports a recognition that

150 See Abrams \& Washington, supra note 95, at 362 ("[A] uthority for an action in public nuisance derived from what is now known as the sovereign's police power and not from tort law."); Halper, supra note 89, at 10,296.

151 See, e.g., Bacon v. Walker, 204 U.S. 311,317 (1907) (noting that police power "embraces regulations designed to promote the public convenience or the general prosperity, as well as regulations designed to promote the public health, the public morals, or the public safety"); Lawton v. Steele, 152 U.S. 133, 136 (1894) (explaining that police power encompasses "everything essential to the public safety, health, and morals").

152 See Huron Portland Cement Co. v. City of Detroit, 362 U.S. 440, 442 (1960) ("Legislation designed to free from pollution the very air that people breathe clearly falls within the exercise of even the most traditional concept of what is compendiously known as the police power."); Lawton, 152 U.S. at 136; Exxon Mobil Corp. v. EPA, 217 F.3d 1246, 1255 (9th Cir. 2000) ("Air pollution prevention falls under the broad police powers of the states, which include the power to protect the health of citizens in the state. Environmental regulation traditionally has been a matter of state authority.").

153 Hadacheck v. Sebastian, 239 U.S. 394, 410 (1915); Halper, supra note 89, at 10,296; Donna Jalbert Patalano, Police Power and the Public Trust: Prescriptive Zoning Through the Conflation of Two Ancient Doctrines, 28 B.C. ENVTL. Afr. L. Rev. 683, 708-09 (2001) (noting "elastic" nature of police power and stating that it "creates protections for the public when individual interests need to yield to general social interests because of social, economic, and political conditions").

154 See generally Lin, supra note 3, at 910-11 (observing that existing regulatory schemes primarily involve regulation of demonstrated risks).

155 In Village of Euclid $v$. Ambler Realty Co., the Supreme Court upheld the power of local authorities to adopt zoning ordinances governing industrial facilities even though such ordinances might exclude facilities that are "neither offensive nor dangerous.” 272 U.S. 365, 388 (1926). The Court explained:

But this is no more than happens in respect of many practice-forbidding laws which this court has upheld although drawn in general terms so as to include individual cases that may turn out to be innocuous in themselves. The inclusion of a reasonable margin to insure effective enforcement, will not put upon a law, otherwise valid, the stamp of invalidity. Such laws may also find their justification in the fact that, in some fields, the bad fades into 
exposure to untested substances constitutes an actionable interference with public rights.

In order to constitute a public nuisance, an interference with public rights generally must be substantial and unreasonable. ${ }^{156}$ At first glance, the requirement of substantiality may appear to be a serious obstacle to asserting a public nuisance claim for the failure to test chemical substances. By virtue of the very failure to test, substantial physical harm usually cannot be shown. ${ }^{157}$ However, a showing of substantial harm is not strictly required where the state seeks only injunctive relief, as opposed to damages. ${ }^{158}$ In order to obtain an injunction against a public nuisance, harm need only be threatened and need not actually have been sustained at all. ${ }^{159}$ Moreover, the responsibility of chemical manufacturers in perpetuating the condition of toxic ignorance argues in favor of a shift in the burden of proving substantiality (or the lack thereof) to chemical manufacturers. ${ }^{160}$

The third element of a public nuisance action, the requirement that the defendant have control of the instrumentality causing the nuisance, is easily satisfied where the nuisance involves a failure to test. After all, the manufacturer is responsible for introducing the chemical into the stream of commerce and has complete control over whether testing is done. This situation is thus distinguishable from the efforts to apply public nuisance doctrine in handgun and lead paint litigation, where the instrumentalities causing the nuisance long ago left the manufacturers' control and arguably became subject to

the good by such insensible degrees that the two are not capable of being readily distinguished and separated in terms of legislation.

Id. at 388-89 (citations omitted). By analogy, the police power extends not only to demonstrably harmful chemicals, but also to chemicals whose effects are currently unknown and that ultimately may pose no health or environmental risks.

156 See supra Part II.A.

157 Three of the four factors suggested by Donald Gifford as relevant to determining the significance of interference with a public right, see supra text accompanying note 116-the degree of harm, its duration, and its severity-will be difficult to demonstrate because of the lack of safety testing.

158 See Restatement (SeCOND) OF TORTS $\$ 821 \mathrm{~B} \mathrm{cmt.} \mathrm{i} \mathrm{(1979)} \mathrm{(“[F]or} \mathrm{damages} \mathrm{to}$ be awarded significant harm must have been actually incurred, while for an injunction harm need only be threatened and need not actually have been sustained at all."); $c f$. People v. McDonald, 137 Cal. App. 4th 521, 538 (2006) (citing Second Restatement of Torts for proposition that "[a] public nuisance may be prosecuted criminally although it has not yet resulted in any significant harm, or indeed any harm to anyone").

159 See Restatement (Second) of Torts $\$ 821 \mathrm{~B} \mathrm{cmt.} \mathrm{i.}$

160 Cf. Wagner, supra note 5, at 1742 (advocating "that at least part of the burden of resolving ... uncertainty falls to the actors whose products and activities create the uncertainty in the first place"). 
superseding causes. ${ }^{161}$ A company that releases untested substances into the marketplace is analogous to a factory that releases smoke and dust to the detriment of its neighbors, and is liable therefore under nuisance theory. Moreover, although a few courts suggest that public nuisance "has historically been tied to conduct on one's own land or property as it affects the rights of the general public,"162 such a view takes an overly narrow approach to public nuisance doctrine even under common law precedents. ${ }^{163}$ Obstructions of public roads and waterways could readily occur without any land ownership by the defendant; indeed, the "catch-all criminal offense" of public nuisance came to encompass such diverse circumstances as diversion of water from a mill, unlicensed stage-plays, and indecent exposure. ${ }^{164}$ The common element in these situations was not the presence of a real property interest; rather control of the obstruction or source of the nuisance sufficed. Such control is readily present when a chemical manufacturer has failed to test the safety of its products.

161 See, e.g., In re Lead Paint Litig., 924 A.2d 484, 501 (N.J. 2007); State v. Lead Indus. Ass'n, 951 A.2d 428, 455 (R.I. 2008). In some of these cases, courts have rejected public nuisance claims out of a concern that such suits could be used to circumvent products liability law pertaining to defective products. See e.g., In re Lead Paint, 924 A.2d at 503; Lead Indus. Ass'n, 951 A.2d at 456. With respect to untested chemicals, however, the allegation is not so much that the chemicals are defective, as that manufacturers have failed to test for defects in the first instance.

162 See, e.g., In re Lead Paint, 924 A.2d at 495; see also Lead Indus. Ass'n, 951 A.2d at 452 (" $[\mathrm{T}] \mathrm{o}$ date, the actions for [public] nuisance in this jurisdiction have been related to land."); Gifford, supra note 88 , at 832 (contending that "a finding of public nuisance historically involved the use of land"). Gifford suggests that confining public nuisance claims to cases involving land makes sense in light of the availability of claims of negligence, strict liability for abnormally dangerous activities, and strict products liability for personal injuries resulting from conduct not involving the use of land. See id. at 833. Public nuisance law, however, incorporates an element of fault and thus cannot be strictly separated from the law of negligence or strict liability. See supra note 98 and accompanying text. In addition, the availability of one cause of action in specific factual circumstances does not necessarily preclude the availability of another. Public nuisance's requirement of interference with a public right reduces any concern that the tort might swallow up other torts and apply to "any unreasonable harm that might result from human interaction." Gifford, supra note 88 , at 833.

163 See 58 Am. Jur. 2D Nuisances $\S 31$, at 592 (2002) (“[A]n action for public nuisance may lie even though neither the plaintiff nor the defendant acts in the exercise of private property rights."); W. Page Keeton et al., Prosser and Keeton on Torts $\$ 86$, at $617-18$ (5th ed. 1984) (distinguishing narrow civil action of private nuisance, "narrowly restricted to the invasion of interests in the use or enjoyment of land," from the "entirely separate" criminal action of public nuisance, "extending to virtually any form of annoyance or inconvenience interfering with common public rights").

164 Keeton et al., supra note $163, \S 86$, at $617-18$. 
Finally, applying public nuisance to the failure to test chemicals raises two additional doctrinal issues. First, some jurisdictions require intent, negligence, or a violation of law as an element of public nuisance. ${ }^{165}$ Such a requirement would be readily met in failure to test cases. By definition, a failure to test involves negligent conduct by a chemical manufacturer: the failure to conduct reasonable health and safety testing. ${ }^{166}$ Second, public nuisance claims would be asserted under state common law, raising the possibility of federal preemption under TSCA. That statute, however, expressly preserves "the authority of any State ... to establish or continue in effect regulation of any chemical substance, mixture, or article containing a chemical substance or mixture."167

\section{An Alternative Public Nuisance Theory Centered on the Right to Information}

Public nuisance theory also can be applied to the problem of untested chemicals under an understanding of "public right" that focuses on harms to personal autonomy. Under this approach, the public right that is interfered with is a procedural right, the right to information, rather than the substantive right against exposure to untested substances. This sort of interference represents a significant departure from the common law examples of public nuisance, but it still falls within public nuisance's broad definition. While the public right to information regarding environmental hazards is a fairly modern concept, it is one that has received growing recognition in recent years. ${ }^{168}$

The adoption of various statutes promoting the dissemination of information about chemical hazards to the public reflects the development of this right. At the federal level, the Emergency Planning and Community Right-to-Know Act ${ }^{169}$ (EPCRA) requires facilities to report annually their releases of chemicals that have been listed as toxic by

165 See supra note 98.

166 The specific measures necessary to satisfy the duty to conduct reasonable testing are considered in Part III of this Article.

16715 U.S.C. $\$ 2617$ (a) (1) (2006). The exceptions to this statutory section provide for preemption where EPA issues a rule mandating testing or otherwise regulating a specific chemical substance. See id. $\$ 2617$ (a)(2). In such circumstances, a state would have no need to bring a public nuisance action for failure to test.

168 Cf. Gary E.R. Hook \& George W. Lucier, The Right to Know is for Everyone, 108 Envtl. Health Persp. Al60, Al60 (2000) (editorial) (noting origins of right to know and arguing that " $[\mathrm{i}] \mathrm{n}$ a free and open society, the concept of 'right to know' seems fundamental").

169 See 42 U.S.C. $\$ \S 11,001-11,050$ (2006). 
Congress. ${ }^{170}$ As required by statute, EPA gathers the data in the Toxics Release Inventory and makes it available to the public. ${ }^{171}$ The Safe Drinking Water Act ${ }^{172}$ requires community water systems to send each customer an annual report on the level of contaminants in the drinking water purveyed by the system and to notify customers of certain violations of the act. ${ }^{173}$ In the workplace, the Occupational Safety and Health Act ${ }^{174}$ requires that employees be "apprised of all hazards to which they are exposed, relevant symptoms and appropriate emergency treatment, and proper conditions and precautions of safe use or exposure."175 In the consumer marketplace, federal statutes and regulations mandate ingredient and nutrition labeling on processed foods, as well as risk labels on pharmaceuticals. ${ }^{176}$ And at the state level, a number of similar measures have been enacted, the most well known of which is California's Proposition 65.177 Passed by popular initiative, this statute requires businesses to warn consumers of products that contain listed carcinogens or reproductive toxins. ${ }^{178}$ Many of the above statutes contain provisions authorizing citizen enforcement for failure to disclose the required information. ${ }^{179}$

170 See id. $\$ 11,023$. EPCRA also requires facilities to provide information to state and local emergency planning groups regarding the quantities of certain hazardous chemicals on site. See id. $\S \S 11,002$ (c), 11,022. The public can obtain much of this information upon request. See id. $\$ 11,021(c)(2)$ (public request for material safety data sheets); id. $\$ 11,022(\mathrm{e})(3)$ (public request for emergency and hazardous chemical inventory forms); id. $\S 11,044$ (a) (public availability of plans, data sheets, forms, and notices).

171 See id. § 11,023(j).

172 Pub. L. No. 95-523, 88 Stat. 1660 (1974) (codified as amended at 42 U.S.C. $\S \S 300 \mathrm{f}-300 \mathrm{j}-26(2006))$.

173 See 42 U.S.C. $\$ \S 300 \mathrm{~g}-3$ (c) (1), (4).

174 Pub. L. No. 91-596, 84 Stat. 1590 (1970) (codified as amended at 29 U.S.C. $\$ \S 651-78(2006))$.

175 See 29 U.S.C. $\S 655$ (b) (7); 29 C.F.R. $\$ 1910.1200$ (2009) (OSHA hazard communication regulation).

176 See, e.g., Nutrition Labeling and Education Act of 1990, Pub. L. No. 101-535, 104 Stat. 2353 (codified as amended primarily at 21 U.S.C. $\$ 343$ (2006)); 21 C.F.R. $\$ 201.57$ (2008) (labeling requirements for prescription drugs).

177 See John D. Echeverria \& Julie B. Kaplan, Poisonous Procedural "Reform": In Defense of Environmental Right-to-Know, 12 Kan. J.L. \& Pub. PoL'y 579, 585 (2003).

178 Cal. Health \& SafeTy Code $\$ 25,249.6$ ("No person in the course of doing business shall knowingly and intentionally expose any individual to a chemical known to the state to cause cancer or reproductive toxicity without first giving clear and reasonable warning ....").

179 See 42 U.S.C. $\$ 11,046$ (a) (1) (authority under EPCRA to bring citizen suits against facility owner or operator for failure to submit information); CAL. HeALTH \& SAFETY CODE $\$ 25,249.7$ (d) (authorizing suits "by any person in the public interest" for Proposition 65 violations if certain conditions met). The failure to provide envi- 
Furthermore, a right of access to environmental information, including toxicity data, is arguably an emerging principle of international law. Principle 10 of the 1992 Rio Declaration on Environment and Development discusses this point:

Environmental issues are best handled with the participation of all concerned citizens, at the relevant level. At the national level, each individual shall have appropriate access to information concerning the environment that is held by public authorities, including information on hazardous materials and activities in their communities, and the opportunity to participate in decision-making processes. States shall facilitate and encourage public awareness and participation by making information widely available. ${ }^{180}$

Although Principle 10 hardly establishes an enforceable right to such information, it does reflect a recognition of the importance of "information on hazardous materials" to human wellbeing and the role of governments in developing and disseminating that information.

The "right-to-know" laws discussed above, as well as Principle 10, share a common rationale of promoting individual autonomy by facilitating the ability of individuals to make choices about the risks to which they are exposed. ${ }^{181}$ The right to know and the right not to be

ronmental risk information that an individual would consider in deciding whether to engage in an activity may be sufficient to establish Article III standing in at least some circumstances. See, e.g., Am. Canoe Ass'n v. City of Louisa Water \& Sewer Comm'n, 389 F.3d 536, 542 (6th Cir. 2004) (holding organization had standing to sue for informational injury of members arising out of defendant's failure to fulfill monitoring and reporting requirements of Clean Water Act permit, where member attested that lack of information "deprived him of the ability to make choices about whether it was 'safe to fish, paddle, and recreate in this waterway'").

180 U.N. Conference on Environment and Development, June 3-14, 1992, Rio Declaration on Environment and Development, princ. 10, U.N. Doc. A/CONF.151/ 5/Rev. 1. (June 14, 1992) (emphasis added).

181 See Kathryn E. Durham-Hammer, Left to Wonder: Reevaluating, Reforming, and Implementing the Emergency Planning and Community Right-to-Know Act of 1986, 29 Colum. J. ENvTL. L. 323, 333 (2004) (describing "creat[ion of] a statutory right-toknow that affords community members an opportunity to make informed decisions about how to respond to environmental risks in their neighborhoods" as one of the primary objectives of EPCRA); Echeverria \& Kaplan, supra note 177, at 590; McGarity \& Shapiro, supra note 27, at 844 ("Members of the public have a legitimate interest in knowing the full health effects of products which receive agency approval so that they can decide for themselves whether to use them."); Clifford Rechtschaffen, The Warming Game: Evaluating Warnings Under California's Proposition 65, 23 Ecolocy L.Q. 303, 314 (1996). In practice, mandatory information disclosure requirements have prompted companies to reduce their emissions or reformulate their products voluntarily. See Bradley C. Karkkainen, Information as Environmental Regulation: TRI and Performance Benchmarking, Precursor to a New Paradigm?, 89 GEO. L.J. 257, 287 (2001); Rechtschaffen, supra, at 341-47. 
exposed to untested substances thus are two sides of the same coin, both safeguarding individual autonomy. The development and disclosure of risk information enable individuals to protect their self-interests and to defend themselves and their families from external threats. ${ }^{182}$ Information disclosure is also critical to democratic decisionmaking, as only an informed citizenry can participate effectively in the political process and make considered judgments. ${ }^{183}$ Ultimately, information disclosure requirements reflect a public desire to hold manufacturers responsible for the effects of their products and suggest the existence of an enforceable public right to be informed. ${ }^{184}$ While this right touches both individual and collective interests, it should be considered a public right because the injury-the lack of information-is shared equally by all members of the public and is supportive of the public right to an unpolluted environment. Moreover, access to accurate information, like access to unobstructed highways, is essential to healthy open markets.

\section{Litigating Public Nuisance for Failure to Test}

A public nuisance cause of action to enforce chemical manufacturers' and importers' duty to test is attractive for a number of reasons. First, it would make the duty to test a meaningful obligation. A cause of action as delineated in this Article would be available upon the introduction of an untested substance into the stream of com-

182 See Echeverria \& Kaplan, supra note 177, at 590; Timothy William Lambert et al., Ethical Perspectives for Public and Environmental Health: Fostering Autonomy and the Right to Know, 111 Envtl. Health Persp. 133, 135 (2003) ("Fostering understanding enables people to think and care for themselves and also to help in the preventive action by assisting other people to stay out of harm's way ....").

183 See Echeverria \& Kaplan, supra note 177, at 590; Rechtschaffen, supra note 181, at 313-15 (noting contentions that right-to-know laws promote economic efficiency and democratic decisionmaking).

$184 C f$. Wagner, supra note 26, at 808-09 ("The legislative history undergirding at least some of the right-to-know laws also supports an inference that the public expects manufacturers to bear responsibility for generating and providing basic information on potentially toxic products and by-products."). The right of citizens to know of the hazards posed by chemicals in the environment around them is analogous to the right of a patient to informed consent under medical malpractice law. See Berger \& Twerski, supra note 23 , at 270-73 (discussing informed consent paradigm). In the latter context, Professors Berger and Twerski have argued that an injured patient who is deprived of information about the risks associated with the use of a drug should have a cause of action even if she is unable to prove that the drug caused her injury. See id. at 259 (describing proposal, which would apply to drugs that are not medically necessary). Causation not only is impossible for many such plaintiffs to prove, but also is largely beside the point: the patient's right of informed consent was violated at the time of nondisclosure. See id. at 272-74. 
merce. We would not have to wait for physical injury before trying to enforce the duty, and causation - a formidable barrier to the filing of toxic tort claims, let alone their successful prosecution-would not be at issue. Second, such a cause of action would enable a measured public response to a public problem. ${ }^{185}$ Because individual members of the public would suffer from virtually the same injury, potential private plaintiffs would not be able to assert the special injury necessary to sue. Rather, only public entities would be able to bring failureto-test claims under a public nuisance theory. ${ }^{186}$ This limitation on the pool of potential plaintiffs would ameliorate concerns that manufacturers would be inundated by lawsuits. And because of limited public resources, state attorneys general would need to be selective in deciding what cases to pursue and which companies to name as defendants. ${ }^{187}$ Third, the relief granted would directly redress the problem. Although damages are sometimes recoverable in public nuisance actions, the most common remedy is injunctive relief. ${ }^{188}$ This general rule would hold true for failure-to-test claims as well. Injunctive relief would be preferable to damages because of the difficulty of determining the economic value of the information not developed. In addition, to the extent that damages might in theory compensate for tangible injuries, it is improbable that plaintiffs would be able to demonstrate injuries caused by exposure to as-yet untested substances. Ultimately, injunctions ordering companies to perform testing in order to manufacture or distribute a chemical within a state would be a particularly appropriate remedy, and courts could tailor compliance deadlines to account for individual circumstances, such as the contin-

185 See Antolini \& Rechtschaffen, supra note 92, at 10,119 (noting that public nuisance "offers a community-oriented remedy").

186 Cf. Sara Zdeb, Note, From Georgia v. Tennessee Copper to Massachusetts v. EPA: Parens Patriae Standing for State Global-Warming Plaintiffs, 96 GEO. L.J. 1059, 1077 (2008) (describing purpose of parens patriae doctrine as "to allow states to vindicate public rights and guard against injuries that might be too widely-shared to support standing for any particular individual").

187 See Calvin Massey, State Standing After Massachusetts v. EPA, 61 FLA. L. Rev. 249, 274 (2009) (contending political processes and limited resources constrain ability of state attorneys general to litigate public rights). Public nuisance actions seeking injunctions to redress a failure to test can be contrasted with product liability actions, which seek to recover damages for past or existing private injuries. See Zoglin, supra note 93 , at 364 (discussing court decision allowing representative public nuisance cause of action for future abatement and distinguishing products liability actions); $c f$. City of Cincinnati v. Beretta U.S.A. Corp., 768 N.E.2d 1136, 1142 (Ohio 2002) (holding that existence of facts suggestive of products liability claim does not preclude public nuisance claim if product unreasonably interferes with public right).

188 See supra note 100 and accompanying text. 
ued distribution of useful or important chemicals for a period of time adequate to allow for testing.

In order to bring public nuisance claims for failure to test, a state would first have to ascertain whether any testing has been done on a particular chemical. Although TSCA has been of limited value in generating toxicity data, ${ }^{189}$ it can play an important role in revealing what, if any, testing has been conducted. First, the requirement of TSCA section 5 that companies provide EPA with notice of new chemicals and significant new uses of existing chemicals provides a useful starting point. ${ }^{190}$ In these notices, companies must submit health data in their control and a description of other toxicity data of which they are aware. ${ }^{191}$ Second, section 8 of TSCA imposes additional disclosure requirements. Section $8(\mathrm{~d})$ requires manufacturers, importers, and processors of chemicals to submit unpublished health and safety studies in their possession, as well as lists of other studies known to them but not in their possession. ${ }^{192}$ Moreover, if manufacturers, processors, or distributors of a substance obtain information that reasonably supports the conclusion that the substance presents a substantial risk of injury to health or the environment, section $8(\mathrm{e})$ requires that information to be provided to EPA. ${ }^{193}$ The section $8(\mathrm{~d})$ obligation applies only to chemicals that have been specifically listed by EPA, ${ }^{194}$ whereas section $8(\mathrm{e})$ is a self-implementing requirement that applies on a continuing basis to all chemicals. ${ }^{195}$

189 See supra Part I.D.

19015 U.S.C. $§ 2604$ (2006).

191 See supra Part I.D.1.

19215 U.S.C. $\$ 2607$ (d) (2006); see Brown ET AL., supra note 64 , at 65-67. Industry compliance with this provision is mixed. See James W. Conrad Jr., Open Secrets: The Widespread Availability of Information About the Health and Environmental Effects of Chemicals, Law \& Contemp. Probs., Summer 2006, at 141, 144 (noting EPA has required reporting of specific information for approximately 1100 chemicals, and submission of health and safety studies for approximately 1000 chemicals); Wagner, supra note 55, at 698-99 \& n.15.

19315 U.S.C. $\$ 2607$ (e); see also TSCA Section 8(e) (requiring notice); Notification of Substantial Risk; Policy Clarification and Reporting Guidance, 68 Fed. Reg. 33,129 (June 3, 2003) (providing notice of EPA's interpretation and enforcement policy of TSCA section 8(3)); Conrad, supra note 192, at 145 (stating EPA has received over 15,000 submissions under $\S 8(\mathrm{e})$ since 1977). EPA also accepts "FYI Submissions"toxicity information voluntarily submitted by companies, organizations, or citizens. See Envtl. Protection Agency, Toxic Substance Control Act Section 8(e) Notices, http://www.epa.gov/oppt/tsca8e/pubs/basicinformation.htm (last visited Dec. 5, 2009).

19440 C.F.R. $\S 716.10$ (2009); id. $\$ 716.120$ (listing substances to which $\S 8$ (d) health and safety data reporting requirements apply).

195 See Brown ET AL., supra note 64, at 67. 
States should be able to obtain most of the health and safety data submitted to EPA pursuant to TSCA or otherwise within the agency's possession. Some of this information is publicly available. Section 8 (e) notices, for instance, are posted on the web. ${ }^{196}$ Toxicity data on a somewhat limited set of substances can also be found online in EPA's Integrated Risk Information System (IRIS), ${ }^{197}$ in toxicological profiles maintained by the Agency for Toxic Substances and Disease Registry, ${ }^{198}$ and in other databases. ${ }^{199}$ Other information in EPA's possession can be obtained through a Freedom of Information Act request. ${ }^{200}$ Although companies often make broad claims that the information they submit to EPA constitutes confidential business information (CBI) that should not be disclosed to the public, ${ }^{201}$ such claims generally should not apply to toxicity information. TSCA explicitly provides, for instance, that CBI protections do not apply to health and safety data submitted to the government under the stat-

196 See Envtl. Protection Agency, 8(e) Notices and FYI Submissions, http:// www.epa.gov/oppt/tsca8e/pubs/8eandfyisubmissions.htm (last visited Dec. 5, 2009).

197 IRIS is a publicly accessible database that contains information on human health effects that may result from exposure to various substances in the environment, including a summary of toxicity data. See Envtl. Protection Agency, Integrated Risk Information System (IRIS), http://cfpub.epa.gov/ncea/iris/index.cfm (last visited Dec. 5, 2009); see also Lin, supra note 15, at 1491 (noting that IRIS is a limited database that "summarizes the EPA's consensus position on the potential adverse effects of over 500 chemicals").

198 ATSDR prepares toxicological profiles for 275 listed substances; each profile includes a discussion of health effects based on a review of known research. See Agency for Toxic Substances \& Disease Registry, Toxicological Profile Information Sheet, http://www.atsdr.cdc.gov/toxpro2.html (last visited Dec. 5, 2009); see also Lin, supra note 15, at 1491 (noting that EPA and ATSDR prioritize the chemicals to be profiled based on the "frequency of occurrence at toxic waste sites, toxicity, and potential for human exposure").

199 Canada is developing chemical toxicity profiles, as mandated by the Canadian Environmental Protection Act of 1999. See Health Canada, Environmental and Workplace Health, http://www.hc-sc.gc.ca/ewh-semt/contaminants/existsub/index-eng. php (last visited Dec. 5, 2009). Similar data will become available as the REACH program is implemented in Europe. See infra Part II.E.2. Legislation enacted by California in September 2008 requires the state to develop a "Toxics Information Clearinghouse" that would collect and distribute environmental and toxicological data on chemicals. See Act of Sept. 29, 2008, 2008 Cal. Legis. Serv. ch. 560 (S.B. 509) (West).

200 See 5 U.S.C. $\$ 552$ (2006).

201 See Julie Yang, Note, Confidential Business Information Reform Under the Toxic Substances Control Act, 2 ENvTL. LAW. 219, 222 (1995); see also 15 U.S.C. § 2613(a) (2006) (prohibiting government disclosure of confidential business information, with some exceptions). 
ute. ${ }^{202}$ The various measures discussed above can help a state to get a sense of what testing has been done, but to complete the picture, direct requests for information-or perhaps even legislation that compels companies to disclose testing efforts and data-may also be necessary.

\section{E. Other Proposals}

Several commentators have proposed other means of addressing chemical manufacturers' failure to test their products. In this section, I briefly compare the leading proposals with the public nuisance approach advocated here. This comparison suggests several advantages to a public nuisance approach, including its simplicity and relatively flexible application.

\section{Liability Without Causation}

One way to address the failure to test would be to impose toxic tort liability without proof of causation. Under one such proposal by Margaret Berger, an injured plaintiff who demonstrates that a chemical manufacturer failed to develop or disseminate information needed to assess latent risks would be entitled to recovery, unless the manufacturer can demonstrate that its product did not cause the plaintiff's injury. ${ }^{203}$ The proposal, in other words, creates a presumption of causation and shifts the burden of disproving causation to the defendant. ${ }^{204}$

20215 U.S.C. $\$ 2613$ (b); see also 40 C.F.R. $\$ 2.306$ (a) (3) (2009) (defining health and safety data); Conrad, supra note 192, at 146 (contending that "TSCA does not provide business confidentiality protection to health and safety studies"). To the extent that such data constitute CBI, states have sometimes been able to access TSCA CBI data through agreements with EPA and industry. See Yang, supra note 201, at 232.

203 Berger, supra note 18, at 2143-44. Under a negligence regime, defendants who meet the requisite standard of care for toxicity testing would not be liable for injuries caused by their products. Id. at 2143 .

$204 I d$. at 2144-45 (allowing manufacturers to raise defenses "that certain adverse health reactions could not plausibly arise from exposure to defendant's product" or "that a particular plaintiff's injury is attributable ... to another cause"). In a similar proposal by Wendy Wagner, plaintiffs would be required to prove the following elements to establish a prima facie case: inadequate testing; foreseeable exposure; and "serious harm that might be causally linked to exposure to the product." Wagner, supra note 26, at 834-35; see also Heidi Li Feldman, Science and Uncertainty in Mass Exposure Litigation, 74 TEx. L. REv. 1, 45 (1995) (suggesting burden of proof be shifted whenever plaintiff can establish uncertainty such that it is not possible to conclude whether substance is safe or harmful to humans). 
Berger contends that eliminating causation and focusing instead on the failure to develop information creates better incentives for investigating risk. ${ }^{205}$ The proposal, like the approach set out in this Article, comprehends toxic ignorance as the root of the problem. Given the lack of toxicity information, eliminating causation improves the prospect of holding defendants liable for morally irresponsible choices. ${ }^{206}$ Berger also suggests that causation does little to further the corrective justice goals of tort law in toxic tort cases and therefore that little is lost by eliminating it as a requirement for recovery. ${ }^{207}$ Unlike run-of-the-mill tort cases, where causation serves to "singl[e] out this plaintiff from the class of persons whom the defendant has endangered,"'208 the heavy reliance on epidemiological data and statistical probabilities to infer causation ${ }^{209}$ in toxic tort cases undermines the notion that causation has singled out the correct plaintiff and the correct defendant. ${ }^{210}$

Imposing liability without causation would put some pressure on manufacturers to carry out testing and would enable more toxic tort victims to bring successful claims. But the latent harm that frequently characterizes toxic exposure would still create insurmountable difficulties in many cases. Although they would be relieved of the formal burden of proving specific causation, plaintiffs, in order to determine whom they should file a complaint against, would still have to link their injury to a particular defendant or group of defendants; this showing would essentially involve a watered-down version of general causation. ${ }^{211}$ On the one hand, such a showing could be quite problematic given our daily exposure to hundreds of chemicals and the lack of testing for many of those chemicals. On the other hand, if courts interpret this requirement leniently, such that any plausible link between exposure and injury might do, the pool of potential plaintiffs-and number of potential trials-could become unmanage-

\footnotetext{
205 Berger, supra note 18, at 2134.

206 See id. at 2132-33.

207 Id.

208 Id. at 2132 (quoting Ernest J. Weinrib, Causation and Wrongdoing, 63 CHI.-KENT L. Rev. 407, 410 (1987)).

209 See Lin, supra note 15, at 1449-50.

210 See Berger, supra note 18, at 2132-33, 2120-26.

211 Berger's proposal intends to relieve plaintiffs of having to prove general causation. Id. at 2145. However, the proposal's requirement that plaintiffs demonstrate exposure and ill health subsequent to such exposure indicates that plaintiffs would still have to draw a link between the two. See id. at 2144; cf. Wagner, supra note 26, at 835 (requiring that plaintiffs show "serious harm that might be causally linked to exposure to the product").
} 
able. $^{212}$ Overwhelming liability could be the result, as companies unable to satisfy their duties are compelled to pay potentially speculative damage amounts. ${ }^{213}$

The proposal set forth in this Article avoids many of the difficulties of Berger's proposal by taking an ex ante approach. Rather than concerning itself with the recovery of damages, the proposal aims to avoid damages in the first instance by mandating reasonable testing of chemicals before and after they enter the stream of commerce. ${ }^{214}$ This focus on the breach of the duty to test sidesteps the difficulties involved in demonstrating causation (albeit in a watered-down version). Unlike Berger's scheme, the instant proposal does not require a plaintiff to identify plausible defendants, nor does it risk casting too wide a net that could impose formidable burdens of liability on an entire industry. Indeed, the proposal guards against potential abuse by offering only injunctive relief and by limiting drastically the pool of possible plaintiffs. The instant proposal thus provides a measured but effective response to the toxic ignorance problem.

\section{Statutory Reform}

Other proposals, rather than relying on the tort system, involve statutory reform. As various commentators have contended, statutory enactments generally possess greater democratic legitimacy than regulatory obligations imposed through parens patriae suits. ${ }^{215}$ Statutory reform allows a directly accountable political body to consider complex problems, weigh competing interests, and set priorities through a relatively public process. ${ }^{216}$ Public nuisance litigation brought by state attorneys general, in contrast, can effectively supplant legislative decisions with detailed decrees proposed by executive branch officials and imposed by an unelected judiciary. ${ }^{217}$ The possibility of such litiga-

212 See Pierce, supra note 19, at 1313-18, 1325.

213 See Kim, supra note 4, at 556.

214 See supra Parts II.B-D.

215 See Donald G. Gifford, Impersonating the Legislature: State Attomeys General and Parens Patriae Product Litigation, 49 B.C. L. Rev. 913, 915, 918, 962 (2008); see also Wagner, supra note 55, at 694 (noting criticisms of "regulation through litigation'" as "an illegitimate end-run around the political process rather than a supplemental institutional mechanism for making products safer").

216 See Gifford, supra note 215, at 962-64; W. Kip Viscusi, Overview, in ReGulation Through Litigation 1, 1 (W. Kip Viscusi ed., 2002) ("The policies that result from litigation almost invariably involve less public input and accountability than government regulation.").

217 See Gifford, supra note 215 , at 919 . Gifford cites the regulatory scheme created through the settlement of tobacco litigation brought by various states as a prime example of how '[s]tate attorneys general and mass products plaintiffs' attorneys 
tion, however, also may counter inertial tendencies of government actors in implementing statutory programs. ${ }^{218}$

One statutory proposal would set up a "super study" chemical research program patterned after the Superfund program for cleaning up hazardous waste sites. ${ }^{219}$ Under this proposal, a federal plan would govern research by private and public institutions, which would be reimbursed for research costs from a general fund supported by taxes on the chemical industry. ${ }^{220}$ Individual chemical producers would be required to reimburse the fund when studies show adverse health effects from their chemicals. ${ }^{221}$ The proposal would allow an agency to identify research priorities and coordinate research efforts while holding the chemical industry responsible for the costs of that research. ${ }^{222}$ As noted earlier, however, chemical manufacturers themselves are generally in the best position to conduct safety testing because of their familiarity with their products and superior access to information. ${ }^{223}$ In addition, the proposal would likely face serious obstacles to enactment, particularly in light of the substantial economic burdens it would place on industry, as well as its similarities to the unpopular Superfund statute. ${ }^{224}$

Another proposed reform would directly require manufacturers to generate a standardized set of information through safety research. ${ }^{225}$ Spelling out the data collection procedures to be followed and the information to be produced would help prevent manufacturers from manipulating testing efforts or results. ${ }^{226}$ A one-sizefits-all approach to testing, however, may be wasteful in some circumstances and inadequate in others. Where standardized information

ended up playing the regulatory roles traditionally handled by Congress, state legislatures, [and regulatory agencies]." Id. at 924-25. But cf. Philip J. Cook \& Jens Ludwig, Litigation as Regulation: Firearms, in Regulation Through LtTigation, supra note 216, at 67,91 (suggesting public lawsuits against gun manufacturers are not undemocratic because they are more likely to influence rather than replace legislative process).

218 See William W. Buzbee, Interaction's Promise: Preemption Policy Shifts, Risk Regulation, and Experimentalism Lessons, 57 EMORY L.J. 145, 155 n.34 (2007).

219 See Lyndon, supra note 30, at 1837.

220 See id. at $1837-38$.

221 See id. at 1837.

222 See id. at $1837-38$.

223 See supra text accompanying notes 26-29.

224 See, e.g., Lori A. Kosakowski, Note, The Inclusion of Passive Migration Under CERCLA Liability: When Is "Disposal" Truly Disposal?, 37 VAL. U. L. Rev. 293, 299 (2002) (noting criticisms of CERCLA as "excessively stringent and costly" and "as an inefficient program plagued by high transaction costs and long delays" (quoting Alfred R. Light, CERCla Law and Procedure Compendium, at I-1 (1992)).

225 See, e.g., Wagner, supra note 5, at 1738-40.

226 See id. at 1739. 
production requirements are difficult to devise-as may well be the case for chemical substances in general-the proposal calls for a precautionary approach in which chemicals are presumed to be harmful until manufacturers produce sufficient evidence to the contrary. ${ }^{227}$ Such an approach could be implemented through a comprehensive regulatory scheme that imposes premarketing, registration, and/or approval requirements on all chemicals. ${ }^{228}$

The European Union adopted one such approach in 2006: the Registration, Evaluation, Authorisation, and Restriction of Chemicals (REACH) program. ${ }^{229}$ REACH requires the registration of all chemicals, including those with a long history of use, over an eleven-year phase-in period. ${ }^{230}$ In the registration process, manufacturers and importers are to submit a technical dossier containing information on each chemical's properties and uses, as well as guidance on safe use. ${ }^{231}$ For chemicals produced in quantities over ten metric tons, companies must also prepare a chemical safety assessment, which documents health and environmental hazards and analyzes whether the substance is persistent, bioaccumulative, and toxic. ${ }^{232}$ While a detailed consideration of the merits of REACH is beyond the scope of this Article, a similarly comprehensive approach would offer significant benefits over TSCA in terms of generating toxicity data. ${ }^{233}$

227 See id. at $1741-42$.

228 See Cranor, supra note 25, at 296-97, 304-10 (proposing manufacturers be required to show that chemicals do not pose risks of harm to developing children before products enter commerce).

229 Council Regulation 1907/2006, Registration, Evaluation, Authorisation and Restriction of Chemicals (REACH), 2006 O.J. (L 396) (EC).

230 Id. arts. 6-7, at 62-66; see also Applegate, supra note 5, at 1390-91 (comparing TSCA and REACH). The registration requirement applies to each substance manufactured or imported in quantities of one ton or more per year, with the exception of substances regulated under other legislation, naturally occurring substances such as minerals, and substances known to present low risks. REACH art. 6 , at $62 ;$ id. art. 7 , at 63-65; id. art. 23, at 94-95 (phase-in dates); id. art. 2, at 48-53 (applicability of provisions).

231 REACH art. 10, at 70.

$232 I d$. art. 14, at 77-79. For more details regarding the preparation of a chemical safety assessment, see European Chems. Agency, Guidance on INformation Requirements and Chemical Safety Assessment, at Part A (2008), available at http://guidance.echa.europa.eu/docs/guidance_document/information_requirements_part_ a_en.pdf?vers $=20 \_08 \_08$.

233 See Applegate, supra note 5, at 1391 (noting registration requirement of REACH "should increase the supply of data well above the TSCA baseline"); Bradley C. Karkkainen, Bottlenecks and Baselines: Tackling Information Deficits in Environmental Regulation, 86 TEx. L. REv. 1409, 1433 (2008) (explaining that REACH not only creates legal mandate to produce information, but also removes incentives "toward willful blindness or strategic nonproduction or nondisclosure of relevant information"); 
Implementation of a comprehensive scheme like REACH in the United States would give manufacturers greater incentives to do basic toxicity research. Significant government resources would be required, however, to develop such a scheme and to process the information submitted. ${ }^{234}$ In addition, a REACH-like regime would face formidable political barriers to enactment. ${ }^{235}$ The inability of Congress to make meaningful changes to TSCA, despite widespread recognition of its shortcomings, suggests the unlikelihood of statutory reform in this area in the near future. ${ }^{236}$ Recent episodes of contaminated consumer products and growing concerns about endocrine disruptors may generate legislation responding to specific concerns, ${ }^{237}$ but the broader problem of untested chemicals presents a more abstract issue that is less likely to generate public support or legislative attention. 238 Unless or until a comprehensive scheme akin to REACH is put in place, public nuisance actions can offer states the opportunity to target chemicals that may warrant testing because of their widespread use, persistent nature, observed effects, or other reasons for concern. Indeed, REACH itself may facilitate such actions, as well as other tort and regulatory efforts in the United States, by generating toxicity data that might suggest the need for further investigation. ${ }^{239}$ Public nuisance actions not only can target individual chemicals for testing, but their case-specific approach also allows testing requirements to be tailored to fit specific situations. Ultimately, public nuisance actions might even facilitate the enactment of comprehensive

of. Cranor, supra note 25 , at 310 (describing REACH as "splendidly simple" in that it bars access to EU market if there is no safety data).

234 See Karkkainen, supra note 233, at 1434.

235 See Wagner, supra note 10, at 639.

236 See id. ("Washington insiders seem to concede that meaningful reform of TSCA is not in the cards; the industry's fortified resistance is simply an insuperable obstacle to any meaningful amendments to increase testing or lower the EPA's burden to impose regulatory restrictions on toxic products.").

237 See, e.g., Lyndsey Layton, Study Links Chemical BPA to Health Problems, WAsH. Post, Sept. 17, 2008, at A3; Jim Yardley \& David Barboza, Despite Warnings, China's Regulators Failed to Stop Tainted Milk, N.Y. Times, Sept. 27, 2008, at A1.

238 See Wagner, supra note 10 , at 639 (concluding TSCA reform to be especially unlikely because "the public is simply not engaged or attuned to these abstract, futuristic worries"); see also Wagner, supra note 55, at 720 ("When the only rallying call is the deficiency of safety information, it is difficult to catalyze others to participate in the political process ....").

239 See Karkkainen, supra note 233, at 1434 (contending that REACH will "facilitat[e] self-help actions to identify and implement safe uses" and could "prompt[ ] EPA to exercise its authority under TSCA to demand further testing of substances deemed harmful by the EU"). 
testing requirements by encouraging industries to support a more predictable alternative to common law litigation. ${ }^{240}$

\section{What Might a Duty to Test Require?}

The discussion thus far has assumed the existence of a duty to test chemicals for toxicity without specifying in detail what that duty might require. Public nuisance actions to enforce that duty will require courts to grapple with its contents. In this Part, I explain how the general duty to test may be translated into concrete and specific requirements. In enforcing the duty to test, courts will have to gain a basic familiarity with toxicity testing methods. This is a manageable task comparable to what courts normally do, and does not demand that courts develop the technical expertise a regulatory agency might possess or to conduct activities better suited to the legislature. ${ }^{241}$ After providing a general overview of toxicity testing methods, including in vitro, in vivo, and epidemiological studies, I suggest that courts focus on in vitro and in vivo options for purposes of determining what sort of testing may be sufficient in a specific case.

\section{A. Toxicity Testing Methods in General}

A primary objective of toxicity testing is to determine the possible hazards associated with exposure to a chemical substance and to characterize the risk in a qualitative or quantitative manner. ${ }^{242}$ Important

240 Cf. Alice Kaswan, The Domestic Response to Global Climate Change: What Role for Federal, State, and Litigation Initiatives?, 42 U.S.F. L. REv. 39, 100 (2007) (making similar argument with respect to climate change litigation); Timothy D. Lytton, Using Tort Litigation to Enhance Regulatory Policy Making: Evaluating Climate-Change Litigation in Light of Lessons from Gun-Industry and Clergy-Sexual-Abuse Lawsuits, 86 TEx. L. REv. 1837, 1837 (2008) (describing various ways in which litigation influences policymaking); Wagner, supra note 55, at 711-27 (discussing examples of how regulatory litigation succeeded in overcoming suppression of adverse information about defendants' products where regulators failed to access or act on this information).

241 In contrast to public nuisance litigation in the context of global warming, in which a ruling in favor of the plaintiffs might require courts to develop a complex regulatory regime, see, e.g., Connecticut v. Am. Elec. Power Co., 406 F. Supp. 2d 265, 272 (S.D.N.Y. 2005), vacated and remanded 582 F.3d 309 (2d Cir. 2009) (listing "transcendently legislative" tasks that court would have to accomplish in order to grant relief in global warming litigation), a public nuisance action for failure to test would simply require courts, in designing the appropriate relief, to determine whether more testing is necessary and to set a testing schedule.

242 See Frank A. Barile, Principles of Toxicolocy Testing 5-6 (2008); Robinson \& THORN, supra note 69, at 1-2; see also Paul Illing, General Overview of the Safety Evaluation of Chemicals, in Alternatrves to Animal Testing, supra note 70, at 1, 4-5 (defining risk assessment and distinguishing "hazard" from "risk"). 
variables involved in this overall assessment are exposure routes and exposure levels. ${ }^{243}$ As a general matter, testing seeks to uncover both acute toxicity-adverse health effects that follow a single or limited number of exposures to a substance-as well as chronic toxicityeffects resulting from continuous or intermittent exposure over extended periods of time. ${ }^{244}$

Broadly speaking, toxicity testing methods can be broken down into threc main categories: in vitro testing, in vivo testing, and epidemiological studies. ${ }^{245}$ In vitro refers to any testing done outside of a living organism using plastic or glass. ${ }^{246}$ This plastic or glass forms an artificial system in which cells or tissues from humans or animals are cultured according to established methodologies. ${ }^{247}$ In vivo testing occurs inside a living organism. ${ }^{248}$ The term usually refers to animal studies conducted in a laboratory or other controlled environment, but also includes human experimentation. ${ }^{249}$ Finally, epidemiological studies examine the relationship, if any, between exposure and effect in a population-for example, whether people become ill as a result of inhaling an accidentally released chemical. ${ }^{250}$ Epidemiological

243 See BARILE, supra note 242, at 15. Exposure levels-the concentration of a substance at the border of an organism-do not necessarily correspond with absorption levels-the amount of a substance that is found in a particular biological system within an organism. See Diether Neubert, Risk Assessment and Preventive Hazard Minimization, in Toxicolocy 1153, 1162-63 (Hans Marquardt et al. eds., 1999).

244 See BARILE, supra note 242, at 89-90; RoBinson \& ThORN, supra note 69, at 3. Generally, chronic toxicity of a particular compound cannot be predicted based on its acute toxicity, or vice versa. See id. at 3.

245 See Illing, supra note 242, at 15 (listing types of hazard information); Joseph Sanders, The Bendectin Litigation: A Case Study in the Life Cycle of Mass Torts, 43 Hastrncs L.J. 301, 321-28 (1992) (discussing three categories of data used to determine safety of Bendectin).

246 "In vitro" translates from Latin to literally mean "in glass." WeBSTER's THIRD InTERNATIONAL DictIONARY 1190 (1986) (defining term "in vitro" as outside the living body and in an artificial environment).

247 See Barile, supra note 242, at 147, 151-73.

248 "In vivo" translates from Latin to mean "in the living." WEBSTER's THIRD INTERNATIONAL Dictionary, supra note 246, at 1190 (defining term "in vivo" as "in the living body of a plant or animal").

249 See Illing, supra note 242 , at 16 ("In vivo toxicity studies are studies carried out in animals or humans. Although the best species for studying effects in humans is humans, ethical considerations limit the type and amount ...." (footnote omitted)).

250 See Lin, supra note 15, at 1448-49: Epidemiological studies can involve other parameters. For example, epidemiologists can use a randomized clinical trial to evaluate new drugs, efficacy of surgical treatments, and screening programs. See LeON Gordis, EPIDEMIOLOGY 115-29 (3d ed. 2004). 
studies alone do not prove causation, however; rather, they reveal correlations between exposure and disease. ${ }^{251}$

Courts tend to view epidemiological studies as the most persuasive and acceptable type of general causation evidence in toxic tort cases because they examine disease rates in human populations. ${ }^{252}$ Epidemiological studies are also critical to clinical practice. Clinical trials involving humans, however, are not a viable option for determining the toxicity of chemicals ex ante because of the ethical and practical difficulties of human experimentation. ${ }^{253}$ And epidemiological studies often may not be helpful or even possible ex post because of the absence of data and the limited ability of such studies to detect chronic risks and small increases in risks. ${ }^{254}$ Given these difficulties, courts should focus on in vitro and in vivo options for purposes of establishing what sort of toxicity testing is sufficient. The following section examines these two options in detail.

\section{B. In Vitro and In Vivo Testing}

\section{In Vitro Methods}

Determining the potential toxic hazards associated with a substance begins with basic testing to identify its physical and chemical properties. ${ }^{255}$ This data, which can shed light on the nature of the substance and the probability of its release, includes, but is not limited to, molecular structure, boiling point, melting point, water solubility, impurities, and general reactivity. ${ }^{256}$ TSCA requires that some-but not all-of this information be submitted to EPA for all new chemicals. $^{257}$ Although this information is insufficient to determine the

251 See Neubert, supra note 243 , at 1165 ("It is one principle of epidemiology that such single studies do not allow us to prove a causal relationship.").

252 See Lin, supra note 15, at 1448.

253 See Mark E. Stelljes, Toxicology for Nontoxicologists 70 (2d ed. 2008).

254 See Lin, supra note 15, at 1449.

255 See Barile, supra note 242, at 15, 59; Horst Spielmann \& Alan M. Goldberg, In Vitro Methods, in Toxicolocy, supra note 243, at 1131, 1135 (“[A]cute toxicity testing . . . requires that a series of physicochemical approaches, databases, and structureactivity relationships be evaluated prior to any biological testing.").

256 See Org. For Econ. Co-operation \& Dev., OECD Guidelines for Testing of Chemicals, Summary of Considerations in the Report from the OECD Expert Group on Physical Chemistry 2-4 (1995), available at http://www.ingentaconnect. com/content/oecd/1607310x/2001/00000001/00000001/9710001e; RoBinson \& THORN, supra note 69 , at $136-37$.

257 See 15 U.S.C. $\$ \S 2604$ (d)(1), 2607(a)(2) (2006) (requiring submission of following information, "insofar as known to the person submitting the notice or insofar as reasonably ascertainable,": common or trade name, chemical identity, molecular 
risks that a substance poses, it can provide some hints as to what toxicity testing should follow. ${ }^{258}$ A substance with a molecular structure similar to that of a known toxin, for instance, may warrant special attention. ${ }^{259}$

Beyond these basic analyses of physical and chemical properties, in vitro methods can serve as an alternative to animal studies for evaluating at least some types of toxic effects. ${ }^{260}$ For example, in vitro tests are commonly employed to screen for potential carcinogens by evaluating mutations caused by exposure to a chemical. ${ }^{261}$ One such test, the Ames test, looks for mutations resulting from exposing a bacterium to a chemical, and can be performed easily, rapidly, and inexpensively. ${ }^{262}$ The test can only serve a rough screening function, however, because of the dissimilarity between bacteria and more complex organisms. ${ }^{263}$ Positive results can be followed up with more complex tests involving cultured mammalian cells or tissues to look for gene or chromosomal mutations. ${ }^{264} \mathrm{~A}$ key insight of in vitro science is that cells and tissues properly grown in vitro retain the properties of their organs of origin. ${ }^{265}$ Accordingly, the results of toxicity tests performed on a cell or tissue culture can be extrapolated to the animal

structure, categories of use, amount to be manufactured or processed, resulting byproducts, number of individuals exposed, and manner of disposal).

258 See BARILE, supra note 242, at 15, 91 (noting influence of chemical structure on toxicity and other properties); see also Neubert, supra note 243, at 1165 tbl.2 (listing data needed for an appropriate risk assessment).

259 See BARILE, supra note 242, at 15, 20. Taking this approach one step further, EPA relies heavily on quantitative structure activity relationship (QSAR) analysis, which studies the biological activity of a chemical compound in relation to its molecular structure, to predict how a structurally analogous chemical may react under the same circumstances. See RoBinson \& THORN, supra note 69, at 137.

260 See RoBinson \& ThORN, supra note 69, at 49-50; Illing, supra note 242 , at 23-24; Spielmann \& Goldberg, supra note 255, at 1131, 1131-33.

261 See Stelljes, supra note 253, at 69 . Because mutations are only one of several steps involved in the development of cancer, an in vitro test result revealing an unusual number of mutations by itself does not demonstrate that a chemical is a carcinogen. See id.

262 See BARILE, supra note 242, at 211-14; RoBinson \& THORN, supra note 69 , at 38; Wagner, supra note 26, at 848 (reporting estimated costs of Salmonella assay at $\$ 2000-\$ 4000)$.

263 See Robinson \& ThORN, supra note 69 , at 38.

264 See BARILE, supra note 242, at 214-15; RoBinson \& THORN, supra note 69 , at 39. Using various types of cells or tissues, in vitro tests can also identify reproductive and developmental effects of chemical exposure. See BARILE, supra note 242, at 229-35 (discussing in vitro techniques to identify reproductive and teratogenic effects); Stelljes, supra note 253, at 69.

265 See BARILE, supra note 242, at 147 (defining in vitro toxicology as "the handling of tissues outside of intact organ systems under conditions that support their growth, 
species from which the culture came. In vitro toxicology avoids popular objections to animal testing and can be performed more quickly and inexpensively than in vivo tests. ${ }^{266}$

In vitro tests, however, are subject to a number of limitations. Although such tests employ cell and tissue cultures derived from living organisms, these cultures cannot duplicate entire functional systems. ${ }^{267}$ Consequently, risk assessments based on findings from in vitro studies must draw a number of inferences that are not required for assessments based on in vivo studies. ${ }^{268}$ Validation-the process of determining that a particular technique is a reliable predictor of toxicity in humans-has been completed for only a handful of in vitro tests. ${ }^{269}$ Moreover, some areas of toxicology simply cannot be addressed using in vitro tests. ${ }^{270}$ Latent effects, for instance, can be difficult to study because of natural limitations in the number of divisions that cell lines generally can undergo. ${ }^{271}$

\section{In Vivo Methods}

In vivo toxicity studies typically involve testing of animals in a controlled laboratory environment. ${ }^{272}$ Studies of different lengths are used to measure different types of toxicity. ${ }^{273}$ Acute studies look for immediate toxic effects from a single exposure or limited number of

differentiation, and stability"); Harry Salem \& Sidney A. Katz, Toxicity Assessment Alternatrves 3-17 (1999); Spielmann \& Goldberg, supra note 255, at 1131.

266 See BARILE, supra note 242, at 148 (noting importance of developing fast, simple, and effective in vitro test systems, in light of rapid rate at which chemicals are developed and marketed); Spielmann \& Goldberg, supra note 255, at 1133 (listing advantages and limitations of in vitro toxicity testing); see also CASARETT AND DOULL's Toxicology: The Basic Science of Poisons 32 (Curtis D. Klassen ed., 6th ed. 2001) [hereinafter CASARETT AND Doull's ToxiCOlogy] (listing typical costs of toxicity tests).

267 See BARILE, supra note 242, at 148 (“[T] he use of cell culture does not purport to represent the whole human organism, but can significantly contribute to our understanding of the workings of its components.").

268 See Neubert, supra note 243, at 1179.

269 See Balls, supra note 70, at 28-41 (describing validation process and difficulties involved).

270 See Robinson \& Thorn, supra note 69, at 52; Heinz-Peter Gelbke et al., Evaluation of Methods for the Registration of Chemicals, in Toxicolocy, supra note 243, at 1115, 1117 (" $[\mathrm{T}]$ he use of animal studies is in some cases, such as pregnancy, the only means of obtaining accurate and specific data for a substance with regard to its hazardous potential in humans.").

271 See Barile, supra note 242, at 153-54.

272 See Illing, supra note 242, at 16.

273 See BARILE, supra note 242, at 89-92; STELIJES, supra note 253, at 61-65. 
exposures. ${ }^{274}$ Subchronic studies look for adverse effects from shortterm, repeated doses of a chemical which do not produce immediate toxic effects. ${ }^{275}$ These studies are intended to mimic exposure patterns of humans exposed to low levels of chemicals on a daily or weekly basis. ${ }^{276}$ Finally, chronic studies examine health effects from continuous or intermittent exposure over long periods of time, from one-tenth of the lifespan of a species up to a lifetime. Such studies generally seek to uncover cancer, reproductive, or developmental effects. ${ }^{277}$ Chronic studies provide the most information regarding potential toxicity, but require the most time, resources, and planning. ${ }^{278}$ Whereas acute studies typically run for about fourteen days and subchronic studies ninety days, chronic studies often last six months to two years. ${ }^{279}$

Traditionally, in vivo studies have served as the basis for human health risk assessment because it is believed that they best mimic human exposure. ${ }^{280}$ In vivo studies can test certain exposure routes that in vitro studies cannot, and they also can test multiple exposure routes. ${ }^{281}$ Moreover, because testing occurs within living organisms with operating physiological systems, there is less of an inferential leap in extrapolating test results to humans. ${ }^{282}$ While no animal species perfectly models the human system, ${ }^{283}$ appropriate species can be

274 See Stelljes, supra note 253, at 61. Results of acute toxicity tests can be graphically represented as a dose-response curve. See RoBinson \& Thorn, supra note 69, at 6. The most common acute test is the median lethal dose $\left(\mathrm{LD}_{50}\right)$ test, which is used to determine the dose of a compound that, when ingested, causes death in half of all test animals over a certain time period. See BARILE, supra note 242, at 73-87; STELLJES, supra note 253 , at 61 .

275 See RoBINSON \& THORN, supra note 69, at 8; STELlJEs, supra note 253, at 63-64 (describing subchronic tests).

276 See Robinson \& ThORN, supra note 69, at 8.

277 See Stelljes, supra note 253, at 66-68.

278 See Robinson \& ThORN, supra note 69, at 9-10; Stelljes, supra note 253, at 64-65. The standard duration of a carcinogenicity test involving rats or mice, for example, is two years. See Stelljes, supra note 253 , at 67.

279 See Robinson \& Thorn, supra note 69, at 6; Stelljes, supra note 253, at 96.

280 See llling, supra note 242, at 16, 24.

281 See Stelljes, supra note 253, at 60; Spielmann \& Goldberg, supra note 255, at 1133 tbl. 2, 1336-37.

282 See Neubert, supra note 243, at 1179 ("Interspecies extrapolations are already loaded with difficulties. It is obvious that the number of these uncertainties is further increased when attempting to extrapolate results from in vitro data to the situation in humans.").

283 See Stelyjes, supra note 253, at 91-105 (discussing issues to consider in extrapolating toxicity data from animal studies to humans). For purposes of determining safe exposure levels in humans, animal studies typically focus on the highest dose that 
selected for study based on their distinct biological and physiological features and the similarity of their systems to human systems. ${ }^{284}$

In vivo studies are likely to be more expensive and time consuming than in vitro studies. ${ }^{285}$ The costs of an in vivo study will depend on a number of variables, including the animal species used, the number of animals being tested, the analyses applied, and the length of the study. ${ }^{286}$ Costs of in vivo studies range from several thousand dollars for an acute toxicity test involving one route of exposure, to hundreds of thousands of dollars for chronic toxicity tests lasting twelve months or more. 287 The number of animals required to demonstrate a toxic effect is inversely proportional to the probability of that effect occurring in a human. ${ }^{288}$ Given the relatively low probability of discovering a toxic effect in any one chemical, ${ }^{289}$ large numbers of test subjects may be needed to demonstrate a causal relationship. ${ }^{290}$ Ultimately, a balance must be struck between cost and ethical concernswhich argue for studies more limited in scope-and comprehensiveness and accuracy in the search for toxic effects. ${ }^{291}$

\section{Applying the Duty to Test in Specific Instances}

Ideally, the data gathered from the studies discussed above would be combined with assessments of human exposure and other data to generate a comprehensive risk assessment estimating the likelihood of

causes no effect in animals-the "no-observed adverse effect level" (NOAEL). Id. at 93.

284 See Stelljes, supra note 253, at 91-93; Shayne C. Gad, Introduction to ANIMAL Models in Toxicology 5-15 (Shayne C. Gad ed., 2d ed. 2007) (discussing factors considered in selecting animal models).

285 See BARILE, supra note 242, at 63 ("The overhead associated with establishing and maintaining an animal care facility may be prohibitive .... Interestingly, the budgets required for animal toxicology testing have, in part, prompted the development of in vitro alternative methods with comparatively less expensive requirements."). A two-year rodent bioassay designed to reveal carcinogenic effects from chronic exposure can cost approximately three million dollars. See Gary E. Marchant, Genetics and the Future of Environmental Policy, in ENVIRonmentalism \& The TeCHNOLOGIES OF TOMORRow 61, 62 (Robert Olson \& David Rejeski eds., 2005).

286 See BariLE, supra note 242, at 63-64.

287 See Casarett and Doull's Toxicology, supra note 266, at 32.

288 See BARILE, supra note 242, at 64.

289 One commentator estimates the probability of occurrence of toxic effects from human exposure to most commercial chemicals at $<0.01 \%$. See id.

290 See id. (noting experiment to detect 1:10,000 rate of toxic effects would require several thousands of animals).

291 See Illing, supra note 242, at 23 ("There is a conflict of interest between the current, animal test based toxic risk assessment/evaluation procedures and the ability to depend on alternatives to animal testing."). 
toxicity from exposure to chemicals in the environment. 292 A "state of the art" risk assessment would draw on the expertise of numerous scientists, including but not limited to those practicing in the fields of biology, chemistry, organic chemistry, physics, mathematics, and biostatistics. 293 Economic and time constraints make such a process impractical if not impossible to apply to all chemical substances, however, ${ }^{294}$ and in the vast majority of cases, a full-blown risk assessment should not be required in order to satisfy the duty to test. Rather, a company should be expected to perform a reasonable amount of testing in light of potential hazards that may be identified. ${ }^{295}$ What specific tests must be conducted will vary depending on the circumstances of each case.

Notwithstanding potential concerns regarding judicial competency to decide whether a company has conducted sufficient testing, ${ }^{296}$ it is worth emphasizing that this is the sort of determination that courts routinely make. ${ }^{297}$ Product liability litigation involving defective pharmaceuticals, for instance, often turns on claims that manufacturers failed to conduct adequate tests to determine drug

292 See Nat'l Research Council, Risk Assessment in the Federal Government 19-28 (1983) (describing four basic steps of risk assessment: hazard identification, dose-response assessment, exposure assessment, and risk characterization); BARILE, supra note 242, at 45-47; STELLJES, supra note 253, at 110.

293 See generally STElljes, supra note 253, at 108-24 (discussing risk assessment); Arpad Somogyi et al., Regulatory Toxicology, in Toxicology, supra note 243, at 1139, 1144-46 (same).

294 See Nat'l Research Council, Science and Decisions, supra note 3, at 3 (noting that "the regulatory risk assessment process is bogged down" and that major risk assessments for some chemicals may take more than ten years).

295 See supra Part I.C.1.

296 See Pierce, supra note 19, at 1312-17 (discussing Wagner proposal to relax causation requirement and expressing skepticism regarding its feasibility); Wagner, supra note 26, at 841-46 (identifying concerns and recommending development of checklist of minimal and "state-of-the-art" testing requirements). Pierce's main concern is that courts would too readily find testing inadequate, imposing sizeable judgments on manufacturers and making socially beneficial products more expensive or unavailable. See Pierce, supra note 19, at 1312-13. These concerns are greatly ameliorated with respect to the cause of action set forth in this Article because only injunctive relief, and not damages, could be granted.

297 See Berger, supra note 18, at 2151 (contending shift in inquiry to adequacy of testing will require determinations of negligence "well-suited to the jury's role as a representative of the community"); E.L. Kellett, Annotation, Manufacturer's Duty to Test or Inspect as Affecting His Liability for Product-Caused Injury, 6 A.L.R.3d 91, 98 (1966) (noting that while manufacturer's duty to test or inspect product "may pose widely varying questions of fact ... these questions are, essentially, answerable through application of basic principles of the law of negligence"). 
safety. ${ }^{298}$ In these and other cases alleging inadequate testing, courts consider various circumstances, including the results of initial safety tests, existing knowledge about related chemicals, consumer complaints, and the economic feasibility of further testing, in determining what additional testing should have been done. ${ }^{299}$

Identifying a standard set of testing requirements for companies to follow would reduce the complexity and increase the predictability of judicial determinations regarding whether the duty to test has been satisfied. One useful starting point is the Screening Information Data Set (SIDS), an internationally agreed upon set of screening tests identified by the Organization for Economic Cooperation and Development (OECD). ${ }^{300}$ The OECD developed the SIDS program with the goal of ensuring the availability of basic toxicity information on international HPV chemicals. ${ }^{301}$ The SIDS, in the OECD's view, represents

298 See, e.g., Sindell v. Abbott Labs., 607 P.2d 924, 926 (Cal. 1980) (recounting plaintiffs' allegations that manufacturers of synthetic hormone DES failed to adequately test drug for safety); Strong v. Am. Cyanamid Co., 261 S.W.3d 493, 509-10 (Mo. Ct. App. 2007) (recounting plaintiff's testimony that manufacturers of oral polio vaccine failed to adequately test vaccine for safety); $i d$. at 511 (noting that "Plaintiff presented evidence that a failure to test the strain material would have an effect on safety," and that "reasonable minds could differ about whether Company's failure to test the strain material resulted in a vaccine that imposed a greater risk").

299 See, e.g., Elam v. Lincoln Elec. Co., 841 N.E.2d 1037, 1043-45 (Ill. App. Ct. 2005) (holding evidence was sufficient to support jury verdict of failure to investigate health hazards associated with welding where plaintiff introduced numerous scientific articles regarding industrial manganese poisoning and where defendants failed to conduct epidemiological study); Willmar Poultry Co. v. Carus Chem. Co., 378 N.W.2d 830, 836-37 (Minn. Ct. App. 1985) (upholding jury instruction that chemical manufacturer had duty to test product and to keep informed of scientific knowledge and discoveries in the field); Dow Chem. Co. v. Mahlum, 970 P.2d 98, 117-18 (Nev. 1998) (upholding jury conclusion that company negligently failed to perform additional safety testing on silicone breast implants), overruled in part on other grounds by GES, Inc. v. Corbitt, 21 P.3d 11, 15 (Nev. 2001); Kellett, supra note 297, at 99 (suggesting relevant considerations include "the dangers to be expected from the product, the existence of effective tests or inspections, their economic feasibility, and the skill and care with which the tests or inspections, if any, were performed").

300 See EPA, Chemical Hazard Data, supra note 6, at 3.

301 Org. for Econ. Co-operation \& Dev., Decision-Recommendation on the Cooperative Investigation and Risk Reduction of Existing Chemicals (1991), available at http://www.regulations.gov/search/Regs/contentStreamer?objectID=09000064 8042d6ad\&disposition=attachment\&contentType=pdf. Under the SIDS program, OECD member countries agreed to cooperate in gathering information regarding HPV chemicals, performing or mandating testing to generate SIDS data, and assessing the need for further testing. See id.; Org. for Econ. Co-operation \& Dev., Description of OECD Work on Investigation of High Production Volume Chemicals, http:// www.oecd.org/document/21/0,3343,en_2649_34379_1939669_1_1_1_1,00.html (last visited Dec. 10, 2009). The OECD defines HPV chemicals as those chemicals pro- 
the minimum amount of data necessary to make an initial hazard assessment of HPV chemicals and incorporates testing in six basic endpoint areas: acute toxicity, chronic toxicity, developmental and reproductive toxicity, mutagenicity, ecotoxicity, and environmental fate. ${ }^{302}$ The SIDS also includes basic information on the identity of the chemical, its physical and chemical properties, uses, and sources and extent of exposure. ${ }^{303}$

The SIDS program sets out a potentially valuable framework for evaluating a company's testing efforts. Courts should be leery, however, of relying on the SIDS as the exclusive metric against which to judge those efforts. On the one hand, the SIDS regime may be inadequate to satisfy the duty to test because the SIDS requires only screening-level data that does not fully measure a chemical's toxicity. ${ }^{304}$ When such data reveals potential hazards, further investigation may be necessary. On the other hand, a complete set of SIDS data may not be necessary in all circumstances. The SIDS requirements, developed in the context of high production volume chemicals, rest on an assumption of widespread occupational, consumer, and environmental exposure. ${ }^{305}$ Where that assumption does not hold true, reasonable testing may involve less than a SIDS analysis. ${ }^{306}$

duced or imported at levels greater than one-thousand tons per year in at least one OECD country or in the European Union. See id.

302 EPA, Chemical HazARD DATA, supra note 6, at 2. EPA estimated in 1998 that the tests necessary to develop the basic set of six SIDS screening test endpoints have a total cost of approximately $\$ 205,000$. Id. at 10 . Estimated costs of different levels of testing for chemicals subject to REACH range from $€ 85,000$ to $€ 325,000$ per substance. See Comm'n of the European Communities, White Paper on Stratecy for a Future Chemicals Policy 15 (2001), available at http://eur-lex.europa.eu/LexOriServ/site/en/com/2001/com2001_0088en01.pdf.

303 EPA, Chemical Hazard Data, supra note 6, at 2-3.

304 Org. for Econ. Co-operation \& Dev., Manual for Investigation of HPV Chemicals: SIDS, the SIDS Plan ANd tHe SIDS Dossier $\$ 2.1$ (2006) [hereinafter OECD, SIDS], available at http://www.oecd.org/dataoecd/13/18/36045056.pdf (describing SIDS as "the minimum amount of data that is required for making an initial hazard assessment"); EPA, Chemical HAzARd Data, supra note 6, at 11 (remarking that for many HPV chemicals, "the SIDS battery of tests will not provide sufficient understanding to adequately assess the hazards and risks"); ENVTL. DEF., supra note 79, at 10, 29 (noting that SIDS data "fall well short of what would be needed to conduct a full hazard or risk assessment," "rel[y] primarily on testing of acute or subchronic toxicity," and do not "address emerging concerns such as development neurotoxicity or endocrine disruption potential").

305 See OECD, SIDS, supra note 304.

306 Moreover, some of the data in a SIDS, such as data on ecotoxicity, is arguably less important to determining whether adequate testing has been done to reasonably protect human health. Data on toxicity to fish, aquatic invertebrates, and algae, for instance, is required in a SIDS, but may not be necessary to satisfy the duty to test. See 
Another metric that courts could look to is the testing required under REACH. ${ }^{307}$ In particular, companies that carry out the chemical safety assessment (CSA) mandated by REACH for chemicals produced in quantities over ten tons could be deemed automatically to have satisfied the duty to test. ${ }^{308}$ The judicial recognition of a "safe harbor" based on performance of a CSA would provide some reassurance to chemical companies who may be fearful that no amount of testing would ever satisfy a court. Such an approach also would establish a readily administrable bright-line rule for companies, courts, and other interested parties.

In a world without transaction costs, determining whether a company has satisfied the duty to test would involve a case-by-case consideration of the facts and of expert opinions regarding what specific tests can reveal. If courts opt for such an approach rather than recognizing a safe harbor based on the performance of a CSA, or in instances where a company has performed some testing short of a full CSA, the courts can follow guiding principles based on the SIDS program and the relative merits of various testing methods. First, basic chemical analysis should be required in all cases. Analysis of fundamental physical and chemical properties, such as molecular structure, boiling point, melting point, vapor pressure, water solubility, impurities, and general reactivity should be done as a matter of routine. Such information is relatively inexpensive to obtain and can be invaluable in identifying potential hazards and routes of exposure. ${ }^{309} \mathrm{Sec}$ ond, simple in vitro screening tests that have been validated should be expected for all chemical substances. The Ames test reveals mutagenicity and is widely recognized as a quick and cost-effective screen for potential carcinogens. ${ }^{310}$ Other scientifically validated in vitro tests, such as tests for skin corrosivity and embryotoxicity, also generate data that can be usefully extrapolated to in vivo exposure

OECD, SIDS, supra note 304, at annex 1, available at http://www.oecd.org/dataoecd/ 13/17/36045066.pdf.

307 I am indebted to Wendy Wagner for this suggestion.

308 See supra text accompanying note 232.

309 Cf. European Chems. AgenCy, supra note 232, at 18-19; OECD, SIDS, supra note $304, \S 2.2 .2$ (listing physical and chemical properties for which SIDS data is required).

310 Cf. Wagner, supra note 26, at 843-44 (recommending judicial development of checklist for adequate testing that "might consist of a single in vitro test, like the widely accepted Salmonella assay, for minimal testing"). Reliance on the Salmonella assay alone, however, is insufficient because it ignores potential types of toxicity other than mutagenicity. Id. 
and should be required. ${ }^{311}$ Although low-cost in vitro tests are not yet available to screen for all types of potential adverse effects, scientists are developing reliable new methods, and once these methods are validated, they can be incorporated into basic testing requirements. ${ }^{312}$ Third, whether further testing should be required will depend on various factors, including data from basic chemical analyses, the results of in vitro screening tests, toxicity data on closely related chemicals, likelihood of exposure, probable exposure routes, practicality of additional testing, and other available information. ${ }^{313}$ More extensive testing than that required to produce the SIDS may be warranted for chemicals used in consumer products, for instance, whereas further testing may be unnecessary for chemicals with more limited exposure potential. ${ }^{314}$ Fourth, given the scientific expertise and judgment at issue, courts should view manufacturers' decisions regarding what tests to conduct with some deference. Manufacturers have a duty to undertake reasonable testing, not the amount of testing that a court would do if it were a manufacturer with unlimited time and resources. This deference does not mean, however, that courts should be blind to the economic and legal incentives for industry to do insufficient safety testing. ${ }^{315}$ Rather, courts should give a hard look at testing decisions but recognize the limits of their own knowledge and experience. ${ }^{316}$ Taken together, these guidelines can add an element of

311 See BARILE, supra note 242, at 175-84; Balls, supra note 70 , at $30-31$ (listing validated in vitro tests).

312 See Stelljes, supra note 253, at 69; Balls, supra note 70, at 31 (listing examples of in vitro methods being validated or prepared for validation). See generally Comm. on Toxicity Testing \& Assessment of Envtl. Agents, Nat'l Research Council, Toxicity Testing in the 21st Century 46, 52 (2007) (advocating efforts to develop toxicity testing paradigm based exclusively on in vitro testing that would identify relevant biologic perturbations of cellular pathways).

313 Cf. OECD, SIDS, supra note $304, \$ 2.3 .1$ (suggesting factors to consider in assessing the need for additional testing beyond data initially gathered under SIDS program).

314 See EPA, Chemical Hazard Data, supra note 6, at 9; OECD, SIDS, supra note $304, \S 2.3 .1$.

315 See supra Part I. With respect to the data gathered under EPA's HPV Challenge Program, for instance, chemical sponsors have been criticized for relying on inappropriate surrogate chemicals or on overly broad chemical categories. See ENVTL. DEF., supra note 79 , at 25 .

316 This hard look review would be comparable to that performed by courts in reviewing agency decisions involving matters of technical expertise. Under such review, courts ensure that an agency "examine[d] the relevant data and articulate[d] a satisfactory explanation for its action including a 'rational connection between the facts found and the choice made." Motor Veh. Mfrs. Ass'n v. State Farm Mut. Auto. Ins. Co., 463 U.S. 29, 43 (1983) (quoting Burlington Truck Lines, Inc v. United 
consistency to a flexible inquiry and offer substantive direction to states assessing whether adequate testing has been done, to companies attempting to satisfy their testing obligations, and to courts charged with evaluating testing efforts.

\section{CONCLUSION}

Public nuisance actions offer a potentially powerful tool to goad chemical manufacturers into performing safety testing that they already should be doing under fundamental principles of tort law and responsible corporate behavior. The range of chemicals possibly subject to such actions is quite broad, but public officials would almost certainly focus their limited resources on a narrow subset of the thousands of chemicals found in commerce. In setting their priorities for investigation and subsequent litigation, officials likely would consider factors relating to both risk and exposure. On the risk side, these factors could include: anecdotal accounts of adverse effects; statistical clusters of symptoms or illness; known or suspected hazards in similar chemicals; or studies suggesting positive correlations between chemical exposure and illness, even if those correlations fall short of statistical significance. On the exposure side, factors worth considering might include: widespread distribution or use of a chemical; intended use or foreseeable misuse of a chemical product; likely exposure among children, pregnant women, and other vulnerable populations; and the tendency of a chemical to disperse in the environment. None of this is to suggest that any of these factors is necessary in order to bring a failure to test claim; rather, these factors are among those that may be relevant to the choice of chemicals to target for public nuisance actions.

Ultimately, a statutory mandate to develop risk assessments for all chemicals in commerce-or even a more limited approach akin to REACH-could serve as a more comprehensive response to the widespread failure of manufacturers, processors, and distributors to conduct adequate testing. Whether such a mandate will be enacted in the near future, however, is uncertain, given the opposition it would likely encounter from the chemical industry. ${ }^{317}$ Public nuisance actions for

States, 371 U.S. 156, 168 (1962)); see also Greater Boston Television Corp. v. FCC, 444 F.2d 841, 850 (D.C. Cir. 1970) (describing court's role to "undertake[ ] a study of the record . . . even as to the evidence on technical and specialized matters").

317 In 2008, Senator Frank Lautenberg and Representatives Hilda Solis and Henry Waxman introduced a bill titled the Kid Safe Chemical Act. H.R. 6100, 110th Cong., 2d Sess. (2008); S. 3040, 110th Cong., 2d Sess. (2008). The bill, which did not make it out of committee hearings would have significantly reformed TSCA. Legislators are planning on reintroducing similar legislation in the near future. See Press Release of 
failure to test can help to address the toxicity gap in the meantime and lay the foundation for a broader statutory mandate. ${ }^{318}$ Such actions can be brought immediately, without any legislative action, and can be brought by one or more states, consistent with their significant role in U.S. environmental policy. ${ }^{319}$ The bringing of failure-totest actions, and the possibility that such actions may be brought, will force more manufacturers to take seriously their obligations to ensure that the chemicals that they introduce into commerce and the environment are reasonably safe.

Senator Lautenberg, Lautenberg: CDC Study Reveals Need to Reform Chemical Safety Standards (Dec. 10, 2009), available at http://lautenberg.senate.gov/newsroom/record.cfm?id=320691.

318 See Kirsten H. Engel, Harmonizing Regulatory and Litigation Approaches to Climate Change Mitigation: Incorporating Tradable Emissions Offsets Into Common Law Remedies, 155 U. PA. L. REv. 1563, 1572-77 (2007) (describing potential for state-initiated public nuisance litigation to trigger federal regulatory response in context of climate change).

319 See generally David E. Adelman \& Kirsten H. Engel, Adaptive Federalism: The Case Against Reallocating Environmental Regulatory Authority, 92 MinN. L. Rev. 1796, 1796 (2008) ("The current system of environmental federalism is thus a dynamic one of overlapping federal and state jurisdiction."); William W. Buzbee, Contextual Environmental Federalism, 14 N.Y.U. ENvTL. L.J. 108, 108 (2005) (contending that "overlap, cooperative federalism structures, and redundant enforcement mechanisms . . . [within] the American system of environmental federalism reduce the risk of regulatory underkill that can result from failures to address environmental ills, as well as failures adequately to fund, implement and enforce written laws and regulations"); Alexandra B. Klass, State Innovation and Preemption: Lessons From State Climate Change Efforts, 41 Loy. L.A. L. Rev. 1653, 1656 (2008) (“[S]tate common law and regulatory efforts to control GHG emissions illustrate today's almost complete linkage between the common law of torts and the regulatory state in areas of public health, safety, and environmental protection."). 
1014

NOTRE DAME LAW REVIEW

[voL. $85: 3$ 